\title{
Concentration maxima of volatile organic iodine compounds in the bottom layer water and the cold, dense water over the Chukchi Sea in the western Arctic Ocean: a possibility of production related to the degradation of organic matter
}

\author{
A. Ooki ${ }^{1}$, S. Kawasaki ${ }^{1}$, K. Kuma ${ }^{1}$, S. Nishino ${ }^{2}$, and T. Kikuchi ${ }^{2}$ \\ ${ }^{1}$ Faculty of Fisheries Sciences, Hokkaido University, Hakodate, Japan \\ ${ }^{2}$ Institute of Arctic Climate and Environment Research, Japan Agency for Marine-Earth Science and \\ Technology, Yokosuka, Japan
}

Correspondence to: A. Ooki (ooki@fish.hokudai.ac.jp)

Received: 28 April 2015 - Published in Biogeosciences Discuss.: 17 July 2015

Revised: 18 November 2015 - Accepted: 3 December 2015 - Published: 15 January 2016

\begin{abstract}
We conducted a shipboard observation over the Chukchi Sea and the Canada Basin in the western Arctic Ocean in September and October 2012 to obtain vertical distributions of four volatile organic iodine compounds (VOIs) in seawater. The VOIs observed in this study were iodomethane $\left(\mathrm{CH}_{3} \mathrm{I}\right)$, iodoethane $\left(\mathrm{C}_{2} \mathrm{H}_{5} \mathrm{I}\right)$, diiodomethane $\left(\mathrm{CH}_{2} \mathrm{I}_{2}\right)$, and chloroiodomethane $\left(\mathrm{CH}_{2} \mathrm{ClI}\right)$. Maximum concentrations of the four VOIs were found in the bottom layer water over the Chukchi Sea shelf, in which layer the maximum concentration of ammonium $\left(\mathrm{NH}_{4}^{+}\right)$also occurred. A significant correlation was observed between $\mathrm{C}_{2} \mathrm{H}_{5} \mathrm{I}$ and $\mathrm{NH}_{4}^{+}$(correlation coefficient $R=0.93, P<0.01, n=64$ ) and between $\mathrm{CH}_{3} \mathrm{I}$ and $\mathrm{NH}_{4}^{+}(R=0.77, P<0.01, n=64)$, suggesting that the production of these VOIs increased with the degradation of organic matter. Over the northern Chukchi Sea shelf-slope area, concentration maxima of $\mathrm{CH}_{2} \mathrm{I}_{2}, \mathrm{CH}_{2} \mathrm{ClI}$, and $\mathrm{CH}_{3} \mathrm{I}$ were found in the subsurface cold, dense water (CDW). A large nitrogen deficit ( $\mathrm{N}$ deficit $=\mathrm{NH}_{4}^{+}+\mathrm{NO}_{3}^{-}+\mathrm{NO}_{2}^{-}-16 \mathrm{PO}_{4}^{3-}$ ) occurred simultaneously in this water, suggesting the production of the three VOIs in the sediment or the bottom layer water over the shelf, probably in association with the degradation of organic matter. We conclude that VOI production over the Chukchi Sea shelf can be largely attributed to the degradation of organic matter that is produced in the highly productive shelf water. High concentrations of $\mathrm{CH}_{2} \mathrm{ClI}$ were also found in the Alaskan Coastal Water (ACW) from the Bering Strait to the surface of the northern Chukchi slope. The VOIs that orig-
\end{abstract}

inated at the Chukchi Sea shelf are expected to be laterally transported to the Arctic Ocean basin through the CDW and the surface ACW.

\section{Introduction}

Volatile organic iodine compounds (VOIs) such as iodomethane $\left(\mathrm{CH}_{3} \mathrm{I}\right)$, iodoethane $\left(\mathrm{C}_{2} \mathrm{H}_{5} \mathrm{I}\right)$, diiodomethane $\left(\mathrm{CH}_{2} \mathrm{I}_{2}\right)$, and chloroiodomethane $\left(\mathrm{CH}_{2} \mathrm{ClI}\right)$ are known to provide iodine atoms to the atmosphere, resulting in catalytic ozone destruction in the troposphere and lower stratosphere (World Meteorological Organization (WMO), 2010). These VOIs have the potential to deplete ozone in boundary layer air on a wide scale (e.g., Carpenter et al., 1999). Arctic ozone depletion during polar sunrise has been indicated, by both observational and theoretical studies (e.g., Spicer et al., 2002), to result from the release of gaseous $\mathrm{Br}_{2}$ and $\mathrm{BrCl}$ from the surface of sea ice and/or snow. More recent theoretical studies have indicated that reactive VOIs such as $\mathrm{CH}_{2} \mathrm{I}_{2}$ would be extremely effective agents for tropospheric Arctic ozone depletion in polar sunrise and that iodine compounds added to a $\mathrm{Br}_{2}-\mathrm{BrCl}$ mixture have a significantly greater ozone depletion effect than additional $\mathrm{Br}_{2}$ and $\mathrm{BrCl}$ molecules only (Carpenter et al., 2005). To understand the flux patterns of VOIs emitted from the ocean to the Arctic air, it is necessary to investigate VOI distribution in seawater and VOI production and loss processes. 
The concentrations of VOIs in seawater of the Arctic Ocean have been measured in the following studies. $\mathrm{CH}_{3} \mathrm{I}$, $\mathrm{CH}_{2} \mathrm{I}_{2}, \mathrm{CH}_{2} \mathrm{ClI}$, and $\mathrm{C}_{3} \mathrm{H}_{7} \mathrm{I}$ were measured around $\mathrm{Ny}$ Ålesund $\left(80^{\circ} \mathrm{N}\right)$ in Spitzbergen, Norway, in September (Schall and Heumann, 1993). $\mathrm{CH}_{3} \mathrm{I}$ was measured in the Greenland and Norwegian seas $\left(63-75^{\circ} \mathrm{N}\right)$ in November (Happell and Wallace, 1996). $\mathrm{CH}_{2} \mathrm{ClI}$ was measured in the Arctic Ocean basin from Barrow, Alaska, to Svalbard (71-90 $\mathrm{N}$; Karlsson et al., 2013). $\mathrm{CH}_{3} \mathrm{I}, \mathrm{C}_{2} \mathrm{H}_{5} \mathrm{I}, \mathrm{CH}_{2} \mathrm{ClI}$, and $\mathrm{C}_{3} \mathrm{H}_{7} \mathrm{I}$ were measured in the Greenland and Norwegian seas $\left(78-82^{\circ} \mathrm{N}\right)$ in June and July (Atkinson et al., 2014). There have been very few measurements of VOIs in the western (Pacific sector) Arctic Ocean (Karlsson et al., 2013), which has vast continental shelves.

In a recent global mapping of VOIs in the surface mixed layer (Ooki et al., 2015), the Chukchi Sea shelf in the western Arctic Ocean was found to have the second-highest concentration of $\mathrm{CH}_{2} \mathrm{ClI}$ (average: $5.7 \mathrm{pmol} \mathrm{L}^{-1}$ ) among all water types (tropical, subtropical, transitional, subpolar, and polar) and ocean areas (shelf, slope, and basin). In the shelfslope areas, $\mathrm{CH}_{2} \mathrm{CII}$ had the largest flux to the atmosphere of three VOIs $\left(\mathrm{CH}_{3} \mathrm{I}, \mathrm{C}_{2} \mathrm{H}_{5} \mathrm{I}\right.$, and $\left.\mathrm{CH}_{2} \mathrm{ClI}\right)$. The vast Chukchi Sea shelf and the adjacent sea areas might have an impact on organic iodine flux to the Arctic atmosphere. Although these various studies have measured the distribution of VOIs, there is no established approach that will enable us to determine how VOI distributions and processes that produce them are impacted by the environmental conditions - including water mass structure and biochemical parameters, such as nutrients and chlorophyll $a$.

The Chukchi Sea shelf is one of the largest continental shelves in the world and has a high biological productivity (e.g., Cota et al., 1996). Three Pacific-origin water masses the Anadyr Water (AnW), Bering Shelf Water (BSW), and Alaskan Coastal Water (ACW) - flow through the Bering Strait into the Chukchi Sea (Grebmeier et al., 1988, 1989). The AnW and BSW form a modified Bering-Shelf-Anadyr water (BSAW). BSAW flowing over the Chukchi Shelf is characterized by low temperature $\left(-1\right.$ to $\left.+2.0^{\circ} \mathrm{C}\right)$ and relatively high salinity $(>31.8)$. It is originally enriched in nutrients and occupies the bulk of the central Chukchi Sea. ACW flowing over the eastern Chukchi Shelf along the coastline of the Alaskan Peninsula is characterized by higher temperatures $\left(>+2{ }^{\circ} \mathrm{C}\right)$ and lower salinity $(<31.8)$. The nutrient level of ACW is originally low compared with that of BSAW. ACW and BSAW are described as the Pacific-origin summer water (PSW) in the western Arctic Ocean. In the Canada Basin, the surface mixed layer has a seasonally low salinity signature $(<30)$ with a relatively low temperature $\left(<+2{ }^{\circ} \mathrm{C}\right)$ in the summer as a result of sea ice melting and river runoff, is called polar mixed layer water (PMLW; Codispoti et al., 2005). Cold, dense water (CDW), which is characterized by its low temperature $\left(-1.7^{\circ} \mathrm{C}\right)$ and relatively high salinity (32-33), is created as a result of sea ice formation and brine production, forming upper and lower halocline layers (An- derson et al., 2013). The CDW that is transported northward on the bottom of the Chukchi Sea shelf is originally derived from Pacific water; thus, CDW over the shelf is described as Pacific-origin winter water (PWW). This CDW (or PWW) flows in the subsurface layer of the Canada Basin. Atlantic water (AW) with high salinity (35) extends from below the halocline layer to the bottom of the Canada Basin. The lower halocline layer water is formed by the mixture of CDW and AW.

In the present study, we conducted a shipboard observation on the R/V Mirai (MR12-E03) over the Chukchi Sea and the Canada Basin in the western Arctic Ocean in September and October 2012. We identified the vertical distributions of four VOIs $\left(\mathrm{CH}_{3} \mathrm{I}, \mathrm{C}_{2} \mathrm{H}_{5} \mathrm{I}, \mathrm{CH}_{2} \mathrm{ClI}\right.$, and $\left.\mathrm{CH}_{2} \mathrm{I}_{2}\right)$ in relation to the water mass structure. We also compare VOIs with nutrients and Chl $a$ and discuss possible processes that produce VOIs in seawater.

\section{Methods}

\subsection{Shipboard observation and seawater sampling}

Shipboard observation was conducted on the R/V Mirai (MR12-E03), which is owned and operated by the Japan Agency for Marine-Earth Science and Technology (JAMSTEC), in the western Arctic Ocean between 15 September and 4 October 2012 as a part of GRENE (Green Network of Excellence) Arctic Climate Change Research Project initiated by the Ministry of Education, Culture, Sports, Science and Technology (MEXT) Japan. General information on MR12-E03 is provided in the cruise report, which is available to the public on the JAMSTEC data website (http: //www.godac.jamstec.go.jp/darwin/e). The locations of the 19 sampling stations for the present study are shown in Fig. 1.

Seawater samples for VOI measurement were collected in Teflon-coated, $10 \mathrm{~L}$ Niskin-X sampling bottles attached to CTD-RMSs (conductivity-temperature-depth probe rosette multisamplers). The sampling depths were 0 (bucket sampling), 5, 10, 20, 30, 40, 50, 100, 200, 500, 1000, 2000, and $3000 \mathrm{~m}$ (or bottom depth $-5 \mathrm{~m}$ ).

Seawater aliquots $(125 \mathrm{~mL})$ were collected in dark glass bottles, overflowing approximately $250 \mathrm{~mL}$ of seawater. To arrest microbial activity, $50 \mu \mathrm{L}$ of saturated mercuric chloride $\left(\mathrm{HgCl}_{2}\right)$ solution, which had been previously bubbled with high-purity nitrogen for $30 \mathrm{~min}$ at $90-100^{\circ} \mathrm{C}$ to remove any contaminating gases, was added to each bottle. The bottles were crimp-sealed with $0.5 \mathrm{~mL}$ headspace, to avoid damage to the glass bottle, using a butyl rubber-lined septum and an aluminum cap. The sample bottles were kept in the dark at $0-4{ }^{\circ} \mathrm{C}$ until pretreatment, typically within 1 month.

Dissolved halocarbons were collected from the seawater samples by the purge-and-trap method. The total volume of seawater $(125 \mathrm{~mL})$ in the sample bottle was introduced to a purge vessel by a high-purity nitrogen car- 


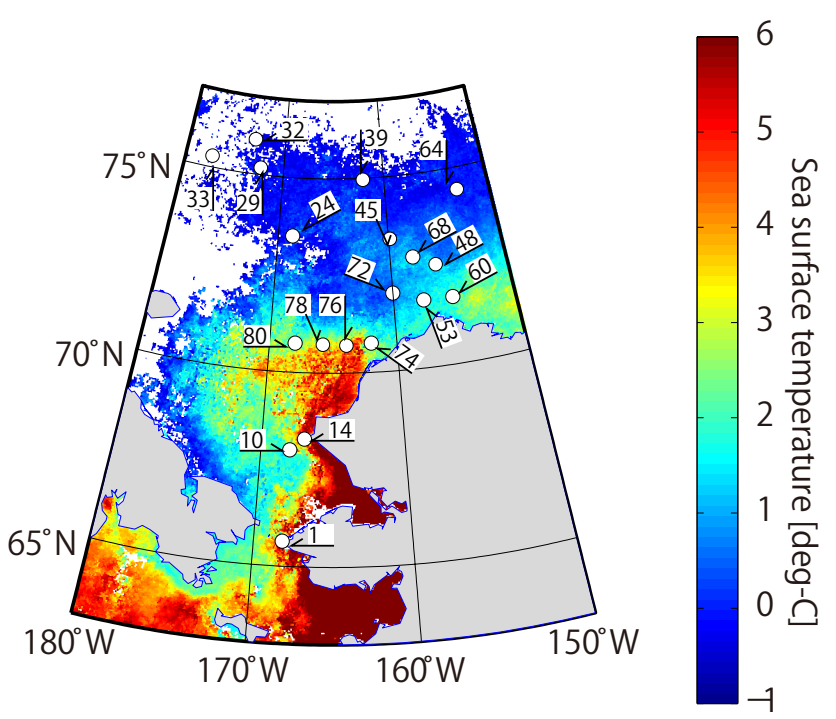

Figure 1. Sampling stations in the present study and sea surface temperature (color) from satellite images from October 2012 (NASA Goddard Space Flight Center Ocean Color; http: //oceancolor.gsfc.nasa.gov/cms/).

rier at $65 \mathrm{~mL} \mathrm{~min}^{-1}$, and the dissolved gases were consecutively purged by bubbling with nitrogen for $35 \mathrm{~min}$. The purged gas sample was collected in a cold trap containing Tenax TA $(10 \mathrm{mg})$ cooled to $-90^{\circ} \mathrm{C}$. This cold-trap sample was sealed with $1 / 16$ in. screw nuts $\left(\right.$ Swagelok $\left.^{\odot}\right)$ and stored in a freezer $\left(-30^{\circ} \mathrm{C}\right)$ until gas-chromatography-massspectrometry (GC-MS) analysis, typically within 7 days. The purge efficiencies for $\mathrm{CH}_{3} \mathrm{I}, \mathrm{C}_{2} \mathrm{H}_{5} \mathrm{I}, \mathrm{CH}_{2} \mathrm{ClI}$, and $\mathrm{CH}_{2} \mathrm{I}_{2}$ were 94, 95, 83, and $66 \%$, respectively (Ooki and Yokouchi, 2011a).

Concentrated VOIs in the cold trap were thermally $\left(200^{\circ} \mathrm{C}\right)$ desorbed and transferred to an automated preconcentration GC-MS analytical system. Details of the GCMS analysis are described elsewhere (Ooki and Yokouchi, 2011a, b). Briefly, the thermally desorbed sample was collected in a trap containing Carboxene 1000 and Carbopak B cooled to $-50^{\circ} \mathrm{C}$ in a small freezer. Concentrated VOIs in this first trap were thermally $\left(200^{\circ} \mathrm{C}\right)$ desorbed and transferred to a second trap, which contained Tenax TA and Carboxene 1000 cooled to $-50^{\circ} \mathrm{C}$. Then, the second trap was heated to $200^{\circ} \mathrm{C}$, and the desorbed components were transferred to a capillary column (Porabond Q, $0.32 \mathrm{~mm}, 50 \mathrm{~m}$ ) in preparation for GC-MS analysis (Agilent 5973, 6890).

To check the possibility of loss and contamination of VOIs in the cold trap during storage in the freezer $\left(-30^{\circ} \mathrm{C}\right)$, two types of standard gases were separately concentrated in each cold trap. The first type is a purge-and-trap standard containing three VOIs in a water bottle $(125 \mathrm{~mL})$. The VOI standards in a standard bottle $(125 \mathrm{~mL})$ was collected in a cold trap using the purge-and-trap method mentioned above. The second type is mixed standard gases containing 13 halocarbons in a high-pressure cylinder. The mixed standard diluted with high-purity nitrogen was introduced to a cold trap. Blank cold traps (no VOI standard) and the two types of standard cold traps were stored in a freezer $\left(-30^{\circ} \mathrm{C}\right)$ for 7 to 30 days. The results of the GC-MS analysis of the standard and blank traps showed that no significant loss or contamination occurred during storage.

\subsection{Chlorophyll $a$ and nutrients}

Chl $a$ concentrations were measured with a fluorescence sensor attached to the CTD observation system. The fluorescence data were calibrated with Chl $a$ concentrations in discrete seawater samples measured using the fluorometric Welshmeyer method (Welshmeyer, 1994). Nutrient $\left(\mathrm{NO}_{3}\right.$, $\mathrm{NO}_{2}, \mathrm{NH}_{4}, \mathrm{SiO}_{2}$, and $\mathrm{PO}_{4}$ ) concentrations were measured by the colorimetric method using a QuAAtro system and in accordance with "The GO-SHIP Repeat Hydrography Manual" (Hydes et al., 2010). Analytical precision was $0.12 \%$ for $\mathrm{NO}_{3}^{-}, 0.21 \%$ for $\mathrm{NO}_{2}^{-}, 0.19 \%$ for $\mathrm{PO}_{4}^{3-}, 0.11 \%$ for $\mathrm{SiO}_{2}$, and $0.34 \%$ for $\mathrm{NH}_{4}^{+}$.

We calculated the value of nitrogen deficit relative to phosphate: $\mathrm{N}$ deficit $=\left[\mathrm{NH}_{4}^{+}\right]+\left[\mathrm{NO}_{3}^{-}\right]+\left[\mathrm{NO}_{2}^{-}\right]-r \times\left[\mathrm{PO}_{4}^{3-}\right]$, where $r$ is a Redfield ratio of 16 . The concentration ratio of nitrogenous nutrient and phosphate in seawater is usually fixed, with $\mathrm{N} / \mathrm{P}=16$. In the anoxic region, such as in bottom sediment, in which nitrate is used in the destruction of organic-matter, phosphate can increase with a decrease in nitrate. We regard the large $\mathrm{N}$ deficit as an indicator of the influence of denitrification on shelf sediment.

\section{Results}

\subsection{Overview of hydrographic condition}

The spatial distribution of surface seawater temperature (SST) is shown in Fig. 1. The water masses were classified according to Grebmeier et al. (1989). We defined the cold dense water (CDW) as having a temperature of -1 to $-1.7^{\circ} \mathrm{C}$ and a salinity of $32-34$, which includes modified CDW as a result of mixture of AW in the lower halocline layer. The warm ACW with temperature $>+2^{\circ} \mathrm{C}$, as shown in light blue to red color in the figure, and a salinity $<31.8$, was found in large parts of the east Chukchi Sea shelf-slope area. The main flow of ACW (temp. $>4{ }^{\circ} \mathrm{C}$ ), shown in both orange and red colors in the figure, was along the coastline of the Alaskan Peninsula. This flow covered the sampling locations of St1, St14, St74, and St76. The ACW seemed to be distributed westward around $70^{\circ} \mathrm{N}$, covering the sampling locations of St78-80. Its eastward flow reached the Barrow Canyon (St53-60) and branched to the northwest along the Chukchi Sea slope from St48 to 45 (light blue in the figure). The PMLW $\left(-1<\right.$ temp. $<2{ }^{\circ} \mathrm{C}$, sal. $\left.<30\right)$ occupied the surface of the northern Chukchi Sea and the Canada Basin, cov- 
Table 1. Hydrographic conditions in the Chukchi Sea and the Arctic Ocean basin.

\begin{tabular}{|c|c|c|c|c|c|c|c|c|c|c|c|c|}
\hline St. & Location & Lat & Long. & $\begin{array}{r}\text { Bottom depth } \\
\text { (m) }\end{array}$ & Area type & $\begin{array}{l}\text { SST } \\
\left({ }^{\circ} \mathrm{C}\right)\end{array}$ & SSS & $\begin{array}{r}\text { MLD } \\
(\mathrm{m})\end{array}$ & $\begin{array}{r}\text { Surface mixed } \\
\text { layer }(\mathrm{m})\end{array}$ & $\begin{array}{r}\text { Subsurface } \\
\text { layer (m) }\end{array}$ & $\begin{array}{r}\text { CDW } \\
(\mathrm{m})\end{array}$ & $\begin{array}{l}\mathrm{AW} \\
(\mathrm{m})\end{array}$ \\
\hline 1 & & 65.7 & 191.8 & 43 & Shelf & 8.1 & 24.1 & 5 & $0-5(\mathrm{ACW})$ & $6-36(\mathrm{ACW})$ & - & - \\
\hline 10 & & 68.0 & 192.0 & 55 & Shelf & 3.9 & 28.9 & 6 & $0-6(\mathrm{ACW})$ & 7-22 (ACW), 23-48 (BSAW) & - & - \\
\hline 14 & Southern & 68.3 & 193.0 & 38 & Shelf & 7.1 & 28.0 & 7 & $0-6(\mathrm{ACW})$ & $7-32(\mathrm{ACW})$ & & \\
\hline 80 & Chukchi & 70.8 & 192.0 & 48 & Shelf & 2.7 & 31.9 & 20 & $0-20(\mathrm{ACW})$ & $21-22$ (ACW), 23-39 (BSAW) & - & - \\
\hline 78 & shelf & 70.7 & 194.0 & 40 & Shelf & 3.1 & 31.2 & 11 & $0-11(\mathrm{ACW})$ & $12-28(\mathrm{ACW}), 29-33$ (BSAW) & - & - \\
\hline 76 & & 70.8 & 196.0 & 47 & Shelf & 4.5 & 29.6 & 15 & $0-15(\mathrm{ACW})$ & $16-39(\mathrm{ACW})$ & - & - \\
\hline 74 & & 70.8 & 198.0 & 43 & Shelf & 4.5 & 31.1 & 33 & $0-33(\mathrm{ACW})$ & $34-35(\mathrm{ACW})$ & - & - \\
\hline 53 & & 71.4 & 202.5 & 124 & Shelf & 3.6 & 29.7 & 9 & $0-9(\mathrm{ACW})$ & $10-24(\mathrm{ACW}), 25-36(\mathrm{BSAW})$ & $37-99$ & $>100$ \\
\hline 60 & Central & 71.7 & 204.9 & 257 & Slope & 3.2 & 30.3 & 6 & $0-6(\mathrm{ACW})$ & 7-25 (ACW), 26-54 (BSAW) & $55-111$ & $>112$ \\
\hline 48 & Chukchi & 72.5 & 204.0 & 1896 & Slope & 4.0 & 26.7 & 9 & $0-9(\mathrm{ACW})$ & $10-40(\mathrm{ACW}), 41-70$ (BSAW) & $71-207$ & $>208$ \\
\hline 68 & Shelf-slope & 72.9 & 202.0 & 1573 & Slope & 2.6 & 28.4 & 14 & $0-14(\mathrm{ACW})$ & 15-20 (ACW), 21-55 (BSAW) & $56-151$ & $>152$ \\
\hline 45 & & 73.3 & 200.0 & 1390 & Slope & 2.7 & 26.9 & 10 & $0-10(\mathrm{ACW})$ & $11-13$ (ACW), 14-81 (BSAW) & $82-203$ & 204 \\
\hline 72 & & 72.0 & 200.0 & 30 & Shelf & 0.2 & 28.2 & 8 & $0-8$ (PMLW) & 9-15 (BSAW) & $16-20$ & - \\
\hline 24 & & 73.5 & 191.3 & 118 & Shelf & -0.2 & 26.9 & 9 & $0-8(\mathrm{PMLW})$ & 9-32 (BSAW) & $32-105$ & \\
\hline 29 & & 75.2 & 187.4 & 453 & Slope & -0.3 & 26.6 & 13 & 0-13 (PMLW) & 14-51 (BSAW) & $52-192$ & $>193$ \\
\hline 33 & & 75.2 & 182.5 & 721 & Slope & 0.0 & 26.7 & 18 & 0-18 (PMLW) & 19-45 (BSAW) & $46-162$ & $>163$ \\
\hline 39 & Northern & 75.0 & 198.1 & 1987 & Slope & 0.8 & 25.7 & 20 & 0-20 (PMLW) & 21-91 (BSAW) & $92-240$ & $>240$ \\
\hline 32 & Slope-basin & 76.0 & 186.0 & 2137 & Basin & -0.4 & 25.8 & 23 & 0-20 (PMLW) & 21-83 (BSAW) & $84-225$ & $>226$ \\
\hline 64 & & 74.5 & 206.0 & 3851 & Basin & 0.1 & 25.1 & 17 & 0-18 (PMLW) & 19-105 (BSAW) & $106-263$ & $>264$ \\
\hline
\end{tabular}

Shelf area with bottom depth $<200 \mathrm{~m}$; slope area with bottom depth between 200 and $2000 \mathrm{~m}$; basin area with bottom depth $>2000 \mathrm{~m}$. Sampling stations in the shelf area are printed in italics. ACW: Alaskan Coastal Water $\left(T>+2{ }^{\circ} \mathrm{C} ; S<31.8\right)$. BSAW: Bering-Shelf-Anadyr water $\left(T=-1 \sim 2.0^{\circ} \mathrm{C}\right)$. PMLW: polar mixed layer water $\left(T<+2{ }^{\circ} \mathrm{C}, S<30\right)$. Subsurface layer: between surface mixed layer $(\mathrm{ML})$ and $\mathrm{CDW}$. CDW: cold dense water (halocline layer; $T=-1 \sim-1.7^{\circ} \mathrm{C} ; S=32 \sim 34$ ). AW: Atlantic water $(S>34.2)$.

ering the sampling locations of St24, St29, St32, St33, St39, St64, and St72.

Geographical information is summarized in Table 1. This information includes sampling position (lat, long.), bottom depth and area type (shelf with bottom depth $<200 \mathrm{~m}$, slope with bottom depth 200-2000 m, or basin with bottom depth $>2000 \mathrm{~m}$ ). The table also includes hydrographic conditions, which include SST, sea surface salinity (SSS), surface mixed layer depth (MLD), and water mass types (ACW, BSAW, PMLW, CDW, or AW). The sampling stations under the influence of ACW are listed in order of latitude from the southernmost St 1 to the northernmost St 45 and those under the influence of PMLW are given in order of bottom depth from the shallowest St72 to the deepest St64. The MLD was defined as the depth where the potential density increases by $0.125 \mathrm{~kg} \mathrm{~m}^{-3}$ compared with the reference depth of $5 \mathrm{~m}$. The subsurface layer was defined as the layer between the surface mixed layer and the CDW or ocean floor.

In the present study, we divided our study area into three groups: "Southern Chukchi shelf", "Central Chukchi shelfslope", and "Northern slope-basin", defined as area between Bering Strait and 71,71 and $74^{\circ} \mathrm{N}$, and north of $74^{\circ} \mathrm{N}$, respectively (Table 2).

In the water structure analysis, the ACW occupied the water column under the main flow of ACW (temp.> ${ }^{\circ} \mathrm{C}$; St 1 , St14, St76, St74), and the BSAW was found in the subsurface layer at the other stations where ACW $\left(4>\right.$ temp. $\left.>2{ }^{\circ} \mathrm{C}\right)$ flows over BSAW. The CDW (or PWW) was found below the subsurface layer at the Central Chukchi shelf-slope and the Northern slope-basin. The AW underlaid the CDW at the deeper stations (bottom depth $124 \mathrm{~m}$ ) of the central and northern areas.

\subsection{Distributions of chlorophyll $a(\mathrm{Chl} a)$, ammonium $\left(\mathrm{NH}_{4}^{+}\right), \mathbf{N}$ deficit, and VOIs}

The average concentrations of $\mathrm{Chl} a, \mathrm{NH}_{4}^{+}, \mathrm{N}$ deficit, and the four studied VOIs $\left(\mathrm{CH}_{3} \mathrm{I}, \mathrm{C}_{2} \mathrm{H}_{5} \mathrm{I}, \mathrm{CH}_{2} \mathrm{I}_{2}\right.$, and $\left.\mathrm{CH}_{2} \mathrm{ClI}\right)$ in the surface mixed layer, subsurface layer, $\mathrm{CDW}$, and $\mathrm{AW}$ at each station are listed in Tables 2-7. The vertical distributions of potential density, $\mathrm{NH}_{4}^{+}, \mathrm{N}$ deficit, and the four VOIs in the Southern Chukchi shelf (St10, St14, St80 and St76) and the Central Chukchi shelf-slope and Northern slope-basin (St24, St29, St64, St32, and St68) are shown in Figs. 2a-g and $3 \mathrm{a}-\mathrm{g}$.

\subsubsection{Chlorophyll $a(\mathrm{Chl} a)$}

The total average concentration of Chl $a$ in all Pacificorigin water $(\mathrm{ACW}+\mathrm{BSAW}+\mathrm{PMLW}+\mathrm{CDW})$ was $0.42 \mu \mathrm{g} \mathrm{L}^{-1}$. The averages of Chl $a$ in ACW in the surface mixed layer $\left(0.75( \pm 0.33 \sigma) \mu \mathrm{g} \mathrm{L}^{-1}\right)$ and the subsurface layer $\left(0.67( \pm 0.26 \sigma) \mu \mathrm{g} \mathrm{L}^{-1}\right)$ were higher than the total average in all Pacific-origin water. The averages in PMLW (0.19 $\left.( \pm 0.17 \sigma) \mu \mathrm{g} \mathrm{L}^{-1}\right)$ and BSAW $\left(0.31( \pm 0.16 \sigma) \mu \mathrm{g} \mathrm{L}^{-1}\right)$ were lower than the total average. In the Northern slope-basin stations, where the PMLW occupied the surface layer, the Chl $a$ concentrations were very low $\left(0.08-0.16 \mu \mathrm{g} \mathrm{L}^{-1}\right)$ in the surface layer. However, concentration maxima were found in the subsurface layer at station $\mathrm{St} 29\left(0.53 \mu \mathrm{g} \mathrm{L}^{-1}\right)$ and the CDW at $\mathrm{St} 33(0.48 \mu \mathrm{g} \mathrm{L}-1$; Table 2). 
(a)

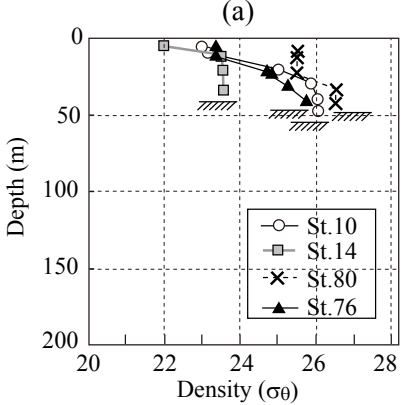

(d)

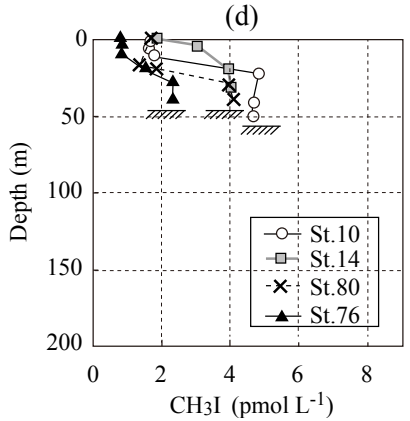

(b)

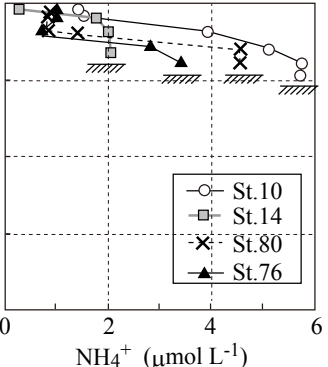

(e)

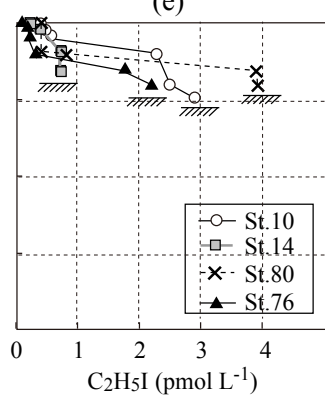

(c)

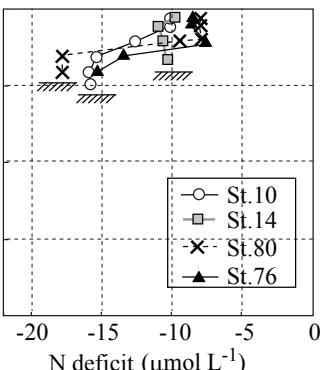

(f)

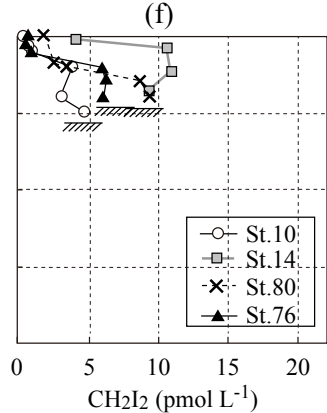

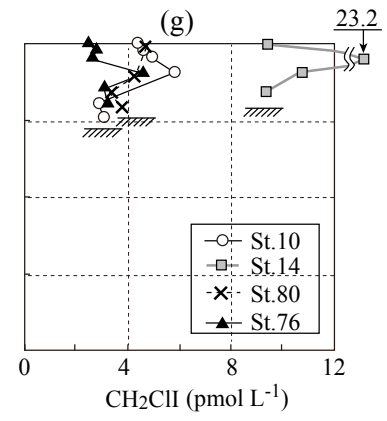

Figure 2. Vertical distributions of potential density (a), $\mathrm{NH}_{4}^{+}$(b), $\mathrm{N}$ deficit (c), $\mathrm{CH}_{3} \mathrm{I}(\mathbf{d}), \mathrm{C}_{2} \mathrm{H}_{5} \mathrm{I}(\mathbf{e}), \mathrm{CH}_{2} \mathrm{I}_{2}$ (f), and $\mathrm{CH}_{2} \mathrm{ClI}(\mathbf{g})$ at $\mathrm{St} 10$, St14, St80, and St76 over the Southern Chukchi shelf.

(a)

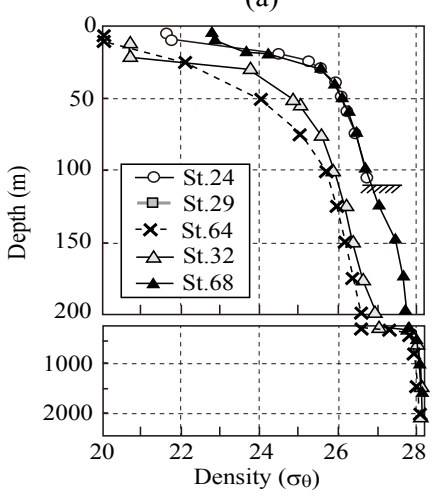

(d)

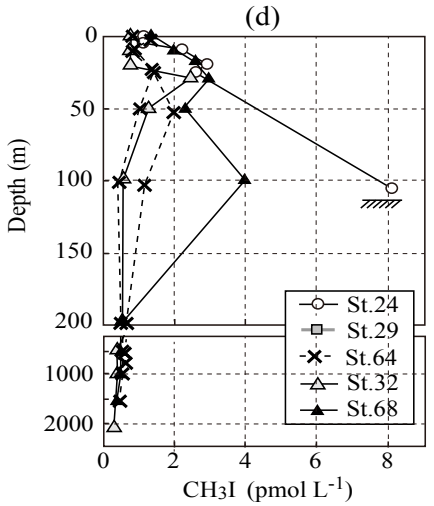

(b)

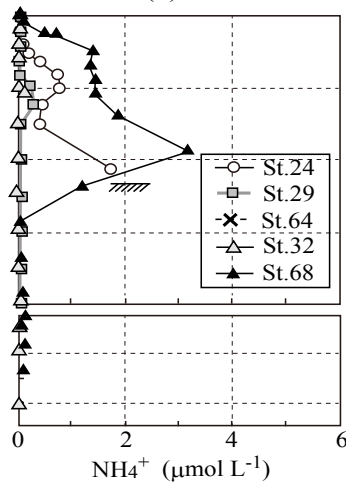

(e)

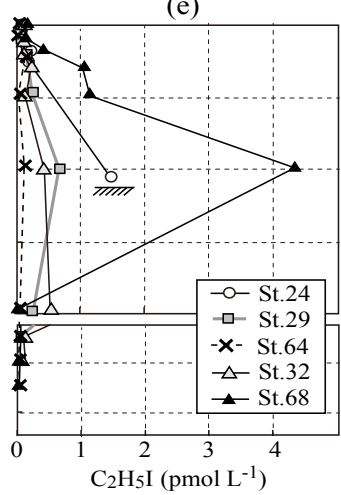

(c)

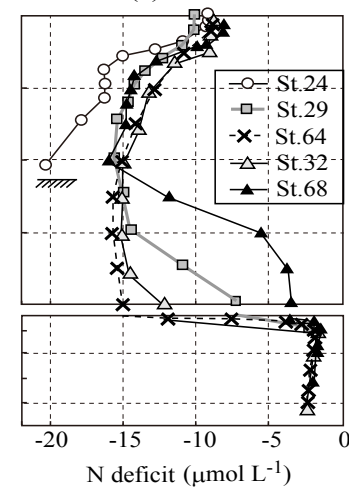

(f)

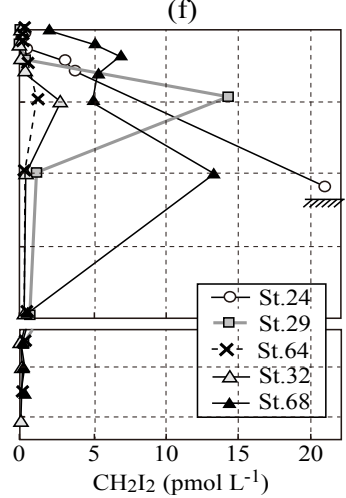

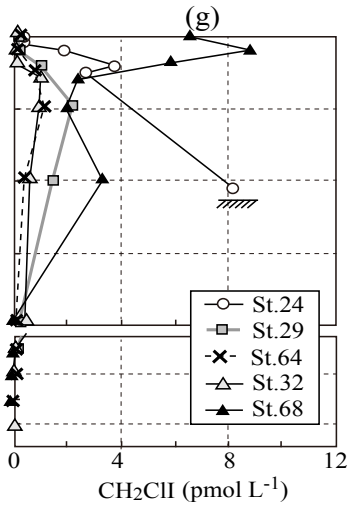

Figure 3. Vertical distributions of potential density (a), $\mathrm{NH}_{4}^{+}$(b), $\mathrm{N}$ deficit (c), $\mathrm{CH}_{3} \mathrm{I}(\mathbf{d}), \mathrm{C}_{2} \mathrm{H}_{5} \mathrm{I}(\mathbf{e}), \mathrm{CH}_{2} \mathrm{I}_{2}(\mathbf{f})$, and $\mathrm{CH}_{2} \mathrm{ClI}(\mathbf{g})$ at $\mathrm{St} 24$, St29, St64, St32, and St68 over the Central Chukchi shelf-slope and the Northern slope-basin. 
Table 2. Concentrations of Chl $a$. bML indicates the subsurface layer.

\begin{tabular}{|c|c|c|c|c|c|c|}
\hline St. & $\begin{array}{r}\mathrm{ML} \\
\mathrm{ACW}\end{array}$ & $\begin{array}{r}\text { ML } \\
\text { PMLW }\end{array}$ & $\begin{array}{r}\mathrm{bML} \\
\mathrm{ACW}\end{array}$ & $\begin{array}{r}\text { bML } \\
\text { BSAW }\end{array}$ & CDW & AW \\
\hline & \multicolumn{5}{|c|}{ Southern Chukchi shelf } & \\
\hline 1 & 1.28 & & 1.24 & & & \\
\hline 10 & 1.14 & & 0.66 & 0.23 & & \\
\hline 14 & 0.98 & & 0.46 & & & \\
\hline 80 & 0.71 & & & 0.21 & & \\
\hline 78 & 0.64 & & 0.85 & 0.22 & & \\
\hline 76 & 0.24 & & 0.29 & & & \\
\hline \multirow[t]{2}{*}{74} & 0.73 & & 0.69 & & & \\
\hline & \multicolumn{6}{|c|}{ Central Chukchi shelf-slope } \\
\hline 53 & 0.93 & & 0.59 & 0.18 & 0.20 & 0.21 \\
\hline 60 & 0.97 & & 0.58 & 0.14 & 0.12 & 0.12 \\
\hline 48 & 0.47 & & 0.51 & & 0.08 & 0.06 \\
\hline 68 & 0.63 & & 0.81 & 0.20 & 0.10 & 0.06 \\
\hline 45 & 0.22 & & & 0.28 & 0.03 & 0.02 \\
\hline 72 & & 0.56 & & 0.69 & 0.27 & \\
\hline \multirow[t]{2}{*}{24} & & 0.14 & & 0.46 & 0.13 & \\
\hline & \multicolumn{6}{|c|}{ Northern slope-basin } \\
\hline 29 & & 0.14 & & $\mathbf{0 . 5 3}$ & 0.11 & 0.07 \\
\hline 33 & & 0.13 & & 0.31 & 0.48 & 0.03 \\
\hline 39 & & 0.16 & & 0.38 & 0.10 & 0.06 \\
\hline 32 & & 0.08 & & 0.29 & 0.04 & 0.01 \\
\hline 64 & & 0.12 & & 0.16 & & 0.05 \\
\hline
\end{tabular}

High Chl $a\left(>0.42 \mu \mathrm{g} \mathrm{L}^{-1}\right)$ values above the total average in Pacific-origin water are denoted in bold.

\subsubsection{Ammonium $\left(\mathrm{NH}_{4}^{+}\right)$and $\mathrm{N}$ deficit}

The total average concentration of $\mathrm{NH}_{4}^{+}$in all Pacificorigin water $(\mathrm{ACW}+\mathrm{BSAW}+\mathrm{PMLW}+\mathrm{CDW})$ was $1.0 \mu \mathrm{mol} \mathrm{L}^{-1}$. Over the Southern Chukchi shelf, the concentration maxima $\left(1.0-5.8 \mu \mathrm{mol} \mathrm{L}{ }^{-1}\right)$ were found in the bottom layer water as shown in Fig. 2b for St10, St80, and St76. The highest concentration $\left(5.8 \mu \mathrm{mol} \mathrm{L} \mathrm{L}^{-1}\right)$ was found near the bottom of the BSAW around the Hope Valley over the Chukchi Sea shelf (St10), where the "Hope Valley biological hotspot" is known to exist (Grebmeier et al., 2015). The dissolved oxygen minimum $\left(243 \mu \mathrm{mol} \mathrm{kg}^{-1}\right)$ and large $\mathrm{N}$ deficit $\left(-12.3 \mu \mathrm{mol} \mathrm{L}{ }^{-1}\right)$ occurred simultaneously near the bottom in this area.

Over the Central Chukchi shelf-slope, concentration maxima $\left(1.3-3.8 \mu \mathrm{mol} \mathrm{L}^{-1}\right)$ were found in the subsurface BSAW and CDW above AW at St24, St53, St60, St68, and St72 (Table 3). The vertical distributions at St24 and St68 are shown in Fig. 3b.

In the Northern slope-basin, $\mathrm{NH}_{4}^{+}$concentrations were very low, with an average of $0.05( \pm 0.07 \sigma) \mu \mathrm{mol} \mathrm{L}^{-1}$. Note that small concentration peaks were found in the CDW at St29 $\left(027 \mu \mathrm{mol} \mathrm{L}^{-1}\right)$ at $60 \mathrm{~m}$ depth, as shown in Fig. 3b. The same was found in the CDW at St $33\left(0.56 \mu \mathrm{mol} \mathrm{L}^{-1}\right)$ at $51 \mathrm{~m}$ depth over the Chukchi Sea slope. The latter is the location where Chl $a$ peaks $\left(0.48-0.53 \mu \mathrm{g} \mathrm{L}^{-1}\right)$ also occurred.

The high $\mathrm{NH}_{4}^{+}$concentration in the Northern slope-basin can be explained as follows. Ammonium regenerated from the organic matter in sediment is added to the bottom layer water over the Chukchi Sea shelf in summer. The CDW, which has an added high amount of $\mathrm{NH}_{4}^{+}$from the sediment of the northernmost end of the Chukchi Sea shelf, has been moved to the slope area (Nishino et al., 2005). The supply of $\mathrm{NH}_{4}^{+}$regenerated from organic matter in the ocean sediment contributes to keeping the $\mathrm{NH}_{4}^{+}$concentration at several micromol per liter in the water column. In contrast, the low concentrations of $\mathrm{NH}_{4}^{+}$in the Northern slope-basin can be explained by the biological consumption of $\mathrm{NH}_{4}^{+}\left(\mathrm{NH}_{4}^{+}\right.$ oxidation as a first step of nitrification) in the water column.

Large $\mathrm{N}$ deficits $\left(-11.1\right.$ to $\left.-20.4 \mu \mathrm{mol} \mathrm{L}^{-1}\right)$ were found in the bottom layer water of the BSAW and CDW from the Southern Chukchi shelf to the Northern slope-basin . The largest $\mathrm{N}$ deficit $\left(-20.4 \mu \mathrm{mol} \mathrm{L}^{-1}\right)$ occurred in the CDW at the northern tip of the Chukchi Sea shelf (St24), as shown in Fig. 3c. These $\mathrm{N}$ deficits largely resulted from denitrification in the ocean sediment over the shelf. Within a narrow depth range in the subsurface waters of the BSAW and CDW over the northern Chukchi Sea shelf-slope and the Canada Basin, the $\mathrm{N}$ deficit minima were coincident with the remarkably high maxima of nutrients, humic-like fluorescent dissolved organic matter (F-DOM), and dissolved $\mathrm{Fe}$ - which are all attributed to emissions from the bottom sediment, which in turn are linked to organic-matter decomposition (Hioki et al., 2014).

\subsubsection{Iodomethane $\left(\mathrm{CH}_{3} \mathrm{I}\right)$}

The total average concentration of $\mathrm{CH}_{3} \mathrm{I}$ in all Pacificorigin water (ACW + BSAW + PMLW + CDW) was $2.2 \mathrm{pmol} \mathrm{L}^{-1}$, which corresponds to the global ocean surface average values (in the range of $2.3-2.6 \mathrm{pmol} \mathrm{L}^{-1}$ ) in shelf slope areas (Ooki et al., 2015). Globally, the polar surface waters had the lowest concentrations of $\mathrm{CH}_{3} \mathrm{I}(1.0$ $1.5 \mathrm{pmol} \mathrm{L}^{-1}$ ) among all water types from tropical to polar (total average $2.3-3.7 \mathrm{pmol} \mathrm{L}^{-1}$ ).

High concentration peaks $\left(>2.2 \mathrm{pmol} \mathrm{L}^{-1}\right)$ above the total average in all Pacific-origin water were occasionally found in the bottom layer water over the Southern Chukchi shelf (Fig. 2d), with average values in the range of 2.1$5.2 \mathrm{pmol} \mathrm{L}^{-1}$, and in the subsurface ACW and BSAW and CDW over the Central Chukchi shelf-slope, with average values in the range of 1.5-8.1 $\mathrm{pmol} \mathrm{L}^{-1}$ (Table 4). These concentrations are consistent with the surface mixed layer averages of $2.5(1.2-4.3) \mathrm{pmol} \mathrm{L}^{-1}$ in the Amundsen Sea and 3.0 (2.1-4.7) $\mathrm{pmol} \mathrm{L}^{-1}$ in the Ross Sea in Antarctica. In summer, considerable algal bloom occurs, and maximum $\mathrm{Chl} a$ concentrations are 8.4-10 $\mathrm{g} \mathrm{L}^{-1}$ (Mattson et al., 2012).

The highest concentration of $\mathrm{CH}_{3} \mathrm{I}\left(8.1 \mathrm{pmol} \mathrm{L}^{-1}\right)$ occurred in the CDW, near the bottom over the northern 
Table 3. Concentrations of $\mathrm{NH}_{4}^{+}$and $\mathrm{N}$ deficit $\left(\mathrm{NH}_{4}^{+} / \mathrm{N}\right.$ deficit $)$.

\begin{tabular}{|c|c|c|c|c|c|c|}
\hline St. & $\begin{array}{r}\text { ML } \\
\text { ACW }\end{array}$ & $\begin{array}{r}\text { ML } \\
\text { PMLW }\end{array}$ & $\begin{array}{l}\text { bML } \\
\text { ACW }\end{array}$ & $\begin{array}{r}\text { bML } \\
\text { BSAW }\end{array}$ & CDW & AW \\
\hline & \multicolumn{6}{|c|}{ Southern Chukchi shelf } \\
\hline 1 & $0.91 /-10.0$ & & $\mathbf{1 . 0 3 / - 1 0 . 8}$ & & & \\
\hline 10 & 1.38/-9.8 & & 2.73/-10.9 & $5.77 /-15.2$ & & \\
\hline 14 & $0.31 /-9.1$ & & $\mathbf{2 . 0 8} /-9.9$ & & & \\
\hline 80 & $1.01 /-7.9$ & & & $4.58 /-16.8$ & & \\
\hline 78 & $0.47 /-7.6$ & & $0.52 /-8.0$ & $3.35 /-14.3$ & & \\
\hline 76 & $1.01 /-8.1$ & & $2.28 /-11.4$ & & & \\
\hline 74 & $1.40 /-11.5$ & & $1.61 /-11.6$ & & & \\
\hline \multicolumn{7}{|c|}{ Central Chukchi shelf-slope } \\
\hline 53 & $0.74 /-10.7$ & & $1.49 /-12.1$ & $3.39 /-15.5$ & $3.83 /-15.0$ & $0.67 /-7.7$ \\
\hline 60 & $0.17 /-9.3$ & & $1.36 /-11.6$ & $1.67 /-13.7$ & 2.15/-11.9 & $0.03 /-2.9$ \\
\hline 48 & $0.04 /-8.5$ & & $0.56 /-10.2$ & & $0.11 /-\mathbf{1 1 . 1}$ & $\mathrm{DL} /-2.3$ \\
\hline 68 & $0.11 /-8.0$ & & $0.50 /-9.2$ & $1.44 /-13.6$ & $3.22 /-16.1$ & $0.07 /-2.1$ \\
\hline 45 & $\mathrm{DL} /-8.8$ & & & DL/-13.2 & DL/-10.9 & $\mathrm{DL} /-2.1$ \\
\hline 72 & & DL/-7.5 & & $\mathrm{DL} /-8.0$ & $1.34 /-15.6$ & \\
\hline 24 & & $0.05 /-9.3$ & & $0.13 /-11.1$ & $1.81 /-20.4$ & \\
\hline \multicolumn{7}{|c|}{ Northern slope-basin } \\
\hline 29 & & $0.02 /-10.0$ & & $0.12 /-12.5$ & DL/-15.5 & $\mathrm{DL} /-4.7$ \\
\hline 33 & & $0.05 /-9.6$ & & $0.02 /-10.2$ & $0.29 /-15.5$ & $\mathrm{DL} /-2.3$ \\
\hline 39 & & $0.03 /-9.2$ & & $0.05 /-\mathbf{1 3 . 2}$ & $0.02 /-\mathbf{1 3 . 6}$ & $0.01 /-2.0$ \\
\hline 32 & & $0.05 /-9.1$ & & $0.02 /-\mathbf{1 2 . 4}$ & $0.02 /-\mathbf{1 3 . 6}$ & DL/-2.1 \\
\hline 64 & & $0.05 /-8.5$ & & $0.02 /-\mathbf{1 2 . 4}$ & & $\mathrm{DL} /-2.2$ \\
\hline
\end{tabular}

High $\mathrm{NH}_{4}^{+}\left(>1.0 \mu \mathrm{mol} \mathrm{L}^{-1}\right)$ values above the total average in Pacific-origin water and large $\mathrm{N}$ deficits $\left(<-11 \mu \mathrm{mol} \mathrm{L}^{-1}\right)$ are denoted in bold.

tip of the Chukchi Sea shelf (St24), where the largest N deficit $\left(-20.4 \mu \mathrm{mol} \mathrm{L}{ }^{-1}\right)$ also occurred. A significant peak $\left(4.0 \mathrm{pmol} \mathrm{L}^{-1}\right)$ occurred in the CDW above the AW over the northern Chukchi Sea slope (St68 in Table 4), coincident with the concentration peak in $\mathrm{NH}_{4}^{+}\left(3.2 \mu \mathrm{mol} \mathrm{L}{ }^{-1}\right)$, as shown in Fig. $2 \mathrm{~b}$ and d. In the northern slope-basin, the $\mathrm{CH}_{3} \mathrm{I}$ concentrations were low with average values in the range of $0.37-1.9 \mathrm{pmol} \mathrm{L}^{-1}$.

\subsubsection{Iodoethane $\left(\mathrm{C}_{2} \mathrm{H}_{5} \mathrm{I}\right)$}

The total average concentration of $\mathrm{C}_{2} \mathrm{H}_{5} \mathrm{I}$ in all Pacificorigin water (ACW + BSAW + PMLW + CDW $)$ was $0.84 \mathrm{pmol} \mathrm{L}^{-1}$, which is $1.5-3$ times the global ocean surface average values in the range of $0.23-0.59 \mathrm{pmol} \mathrm{L}^{-1}$ in shelf-slope areas (Ooki et al., 2015).

High concentration peaks $\left(>0.84 \mathrm{pmol} \mathrm{L}^{-1}\right)$ above the total average in Pacific-origin water were occasionally found in the bottom layer water over the Southern Chukchi shelf (average values in the range of $0.9-3.9 \mathrm{pmol} \mathrm{L}^{-1}$ in Table 5), as shown in Fig. 2e, and in subsurface BSAW and CDW over the Central Chukchi shelf-slope (average values in the range of $1.2-4.4 \mathrm{pmol} \mathrm{L}^{-1}$ ), as shown in Fig. 3e.

The highest concentration of $\mathrm{C}_{2} \mathrm{H}_{5} \mathrm{I}\left(4.4 \mathrm{pmol} \mathrm{L}^{-1}\right)$ occurred in the CDW over the central Chukchi Sea slope (St68), at which depth a large $\mathrm{N}$ deficit $\left(-13.2 \mu \mathrm{mol} \mathrm{L}^{-1}\right)$ and high concentration of $\mathrm{NH}_{4}^{+}\left(3.2 \mu \mathrm{mol} \mathrm{L}{ }^{-1}\right)$ occurred simultaneously. In the Northern slope-basin, the $\mathrm{C}_{2} \mathrm{H}_{5} \mathrm{I}$ concentrations were low (detection limit, DL, $-0.70 \mathrm{pmol} \mathrm{L}^{-1}$ ). A small peak in $\mathrm{C}_{2} \mathrm{H}_{5} \mathrm{I}\left(1.5 \mathrm{pmol} \mathrm{L}^{-1}\right)$ was found in the $\mathrm{CDW}$ over the northern tip of the Chukchi Sea shelf (St24), where the $\mathrm{CH}_{3} \mathrm{I}$ maximum and a large $\mathrm{N}$ deficit occurred simultaneously.

\subsubsection{Diiodomethane $\left(\mathrm{CH}_{2} \mathrm{I}_{2}\right)$}

Very high levels of $\mathrm{CH}_{2} \mathrm{I}_{2}\left(30-47 \mathrm{pmol} \mathrm{L}^{-1}\right)$ were found in the ACW at the Bering Strait (St1). Similar high levels of $\mathrm{CH}_{2} \mathrm{I}_{2}$ (average: 23 pmol L ${ }^{-1}$; min (below DL)-max: $\left.(<0.9)-48 \mathrm{pmol} \mathrm{L}^{-1}\right)$ were reported in the macroalgal field seawater in the fjord of $\mathrm{Ny}$ Alesund $\left(80^{\circ} \mathrm{N}, 12^{\circ} \mathrm{E}\right)$ on Spitzbergen, Norway (Schall and Heumann, 1993). The total average concentration of $\mathrm{CH}_{2} \mathrm{I}_{2}$ in all Pacific-origin water (ACW + BSAW + PMLW + CDW) except for the Bering Strait water (St1) was $4.4 \mathrm{pmol} \mathrm{L}^{-1}$, which is within the range of surface averages from $2.5 \mathrm{pmol} \mathrm{L}^{-1}$ in the coastal area $\left(10 \mathrm{~km}\right.$ offshore) of the English Channel $\left(50^{\circ} \mathrm{N}, 4^{\circ} \mathrm{W}\right.$; Archer et al., 2007) to $6.2 \mathrm{pmol} \mathrm{L}^{-1}$ in the fjord of $\mathrm{Ny}$ Ålesund (Schall and Heumann, 1993). High concentrations (> $4.4 \mathrm{pmol} \mathrm{L}^{-1}$ ) were found in the bottom layer water of 
Table 4. Concentrations of $\mathrm{CH}_{3} \mathrm{I}$ in each water type.

\begin{tabular}{|c|c|c|c|c|c|c|}
\hline St. & $\begin{array}{r}\text { ML } \\
\text { ACW }\end{array}$ & $\begin{array}{r}\text { ML } \\
\text { PMLW }\end{array}$ & $\begin{array}{r}\text { bML } \\
\text { ACW }\end{array}$ & $\begin{array}{r}\text { bML } \\
\text { BSAW }\end{array}$ & CDW & AW \\
\hline & \multicolumn{6}{|c|}{ Southern Chukchi shelf } \\
\hline 1 & 3.4 & & 5.20 & & & \\
\hline 10 & 1.7 & & 3.35 & 4.70 & & \\
\hline 14 & 2.5 & & 4.05 & & & \\
\hline 80 & 1.7 & & & 4.05 & & \\
\hline 78 & 1.2 & & 1.45 & 2.75 & & \\
\hline 76 & 0.9 & & 2.13 & & & \\
\hline 74 & 2.2 & & 2.40 & & & \\
\hline \multicolumn{7}{|c|}{ Central Chukchi shelf-slope } \\
\hline 53 & 1.5 & & 2.30 & 4.30 & 4.45 & 1.10 \\
\hline 60 & 2.0 & & 2.35 & 2.65 & 2.10 & 0.30 \\
\hline 48 & 1.4 & & 3.13 & & 0.65 & 0.50 \\
\hline 68 & 1.7 & & 2.60 & 2.65 & 4.00 & 0.58 \\
\hline 45 & 1.1 & & & 1.50 & 0.60 & 0.27 \\
\hline 72 & & 1.30 & & 1.50 & 3.70 & \\
\hline 24 & & 1.10 & & 2.57 & 8.10 & \\
\hline \multicolumn{7}{|c|}{ Northern slope-basin } \\
\hline 29 & & 1.00 & & 1.80 & 1.20 & 0.75 \\
\hline 33 & & 1.15 & & 1.40 & 1.60 & 0.63 \\
\hline 39 & & 0.93 & & 1.20 & 0.70 & 0.50 \\
\hline 32 & & 0.80 & & 1.90 & 0.60 & 0.37 \\
\hline 64 & & 0.87 & & 1.03 & & 0.48 \\
\hline
\end{tabular}

High $\mathrm{CH}_{3} \mathrm{I}\left(>2.2 \mathrm{pmol} \mathrm{L}^{-1}\right)$ values above the total average in Pacific-origin water are denoted in bold.

the Southern Chukchi shelf and the subsurface layer of the ACW, BSAW, and CDW over the central to northern Chukchi shelf-slope areas, as shown in Figs. $2 \mathrm{f}$ and $3 \mathrm{f}$. The low concentrations $\left(0.80-1.50 \mathrm{pmol} \mathrm{L}^{-1}\right)$ occasionally found in the surface mixed layer water over the shelf (St76 and St45 in Table 6) are probably due to the photolysis of $\mathrm{CH}_{2} \mathrm{I}_{2}$ in seawater (Jones and Carpenter, 2005).

A significant peak in $\mathrm{CH}_{2} \mathrm{I}_{2}\left(20.9 \mathrm{pmol} \mathrm{L}^{-1}\right)$, which is the highest concentration other than the Bering Strait samples, was found in the CDW, near the bottom over the northern tip of the Chukchi Sea shelf (St24 in Fig. 3f). The largest $\mathrm{N}$ deficit and the $\mathrm{CH}_{3} \mathrm{I}$ maximum also occurred in this water. In the Northern slope-basin, the lowest levels of $\mathrm{CH}_{2} \mathrm{I}_{2}$ (DL: $-0.05 \mathrm{pmol} \mathrm{L}^{-1}$ ) were found in the surface mixed layer and the underlying deeper AW. In contrast, significant peaks in $\mathrm{CH}_{2} \mathrm{I}_{2}\left(0.47-14 \mathrm{pmol} \mathrm{L}^{-1}\right)$ were found in the subsurface BSAW and CDW over the slope-basin area. The peak concentrations decreased with increasing bottom depth from the shelf (St24) to the far basin (St64).

\subsubsection{Chloroiodomethane $\left(\mathrm{CH}_{2} \mathrm{CII}\right)$}

The total average concentration of $\mathrm{CH}_{2} \mathrm{ClI}$ in all Pacificorigin water (ACW + BSAW + PMLW + CDW) was $5.0 \mathrm{pmol} \mathrm{L}^{-1}$, which is within the global ocean surface aver-
Table 5. Concentrations of $\mathrm{C}_{2} \mathrm{H}_{5} \mathrm{I}$ in each water type.

\begin{tabular}{|c|c|c|c|c|c|c|}
\hline St. & $\begin{array}{r}\mathrm{ML} \\
\mathrm{ACW}\end{array}$ & $\begin{array}{r}\text { ML } \\
\text { PMLW }\end{array}$ & $\begin{array}{r}\text { bML } \\
\text { ACW }\end{array}$ & $\begin{array}{r}\text { bML } \\
\text { BSAW }\end{array}$ & CDW & AW \\
\hline & \multicolumn{6}{|c|}{ Southern Chukchi shelf } \\
\hline 1 & 0.50 & & 1.58 & \multirow{2}{*}{\multicolumn{3}{|c|}{2.70}} \\
\hline 10 & 0.45 & & 1.45 & & & \\
\hline 14 & 0.30 & & 0.70 & \\
\hline 80 & 0.53 & & & \multicolumn{3}{|l|}{3.90} \\
\hline 78 & 0.30 & & 0.35 & \multicolumn{3}{|l|}{2.55} \\
\hline 76 & 0.17 & & 1.40 & & & \\
\hline \multirow[t]{2}{*}{74} & 0.83 & & 0.90 & & & \\
\hline & \multicolumn{6}{|c|}{ Central Chukchi shelf-slope } \\
\hline 53 & 0.40 & & 0.85 & 2.70 & 2.95 & 0.70 \\
\hline 60 & 0.30 & & 0.85 & 1.30 & 1.90 & 0.10 \\
\hline 48 & 0.15 & & 0.43 & & 0.30 & 0.07 \\
\hline 68 & 0.20 & & 0.50 & 1.15 & 4.40 & 0.10 \\
\hline 45 & 0.13 & & & 0.17 & 0.25 & 0.07 \\
\hline 72 & & 0.23 & & 0.30 & 2.10 & \\
\hline \multirow[t]{2}{*}{24} & & 0.10 & & 0.17 & 1.50 & \\
\hline & \multicolumn{6}{|c|}{ Northern slope-basin } \\
\hline 29 & & 0.10 & & 0.25 & 0.70 & 0.20 \\
\hline 33 & & 0.05 & & 0.10 & 0.55 & 0.00 \\
\hline 39 & & 0.13 & & 0.20 & 0.25 & 0.10 \\
\hline 32 & & 0.10 & & 0.15 & 0.45 & 0.07 \\
\hline 64 & & 0.10 & & 0.17 & & 0.08 \\
\hline
\end{tabular}

High $\mathrm{C}_{2} \mathrm{H}_{5} \mathrm{I}\left(>0.84 \mathrm{pmol} \mathrm{L}^{-1}\right)$ values above the total average in Pacific-origin water are denoted in bold.

age values in the range of $3.7-6.6 \mathrm{pmol} \mathrm{L}^{-1}$ in shelf-slope areas (Ooki et al., 2015). High concentrations of $\mathrm{CH}_{2} \mathrm{ClI}$ were found in all the ACW samples except for St76, with an average of $8.7 \pm 3.6(1 \sigma) \mathrm{pmol} \mathrm{L}^{-1}$ from the Bering Strait to the Central Chukchi shelf-slope (Table 7). Low concentrations of $\mathrm{CH}_{2} \mathrm{I}_{2}$ in the surface $\mathrm{ACW}$ were occasionally found over the shelf (St76) and slope (St45). The occasional low concentrations of $\mathrm{CH}_{2} \mathrm{I}_{2}$ in the surface layer are attributed to photochemical degradation. Since the photolysis rate of $\mathrm{CH}_{2} \mathrm{ClI}$ is much slower than that of $\mathrm{CH}_{2} \mathrm{I}_{2}$ in seawater (Jones and Carpenter, 2005), $\mathrm{CH}_{2} \mathrm{ClI}$ in the surface layer would exist for a longer time than $\mathrm{CH}_{2} \mathrm{I}_{2}$. The lateral transport of $\mathrm{CH}_{2} \mathrm{CII}$ and $\mathrm{CH}_{2} \mathrm{I}_{2}$ will be discussed in Sect. 4.4.

A high concentration peak in $\mathrm{CH}_{2} \mathrm{ClI}\left(11.0 \mathrm{pmol} \mathrm{L}^{-1}\right)$ was found in the CDW, near the bottom over the northern tip of the Chukchi Sea shelf (St24 in Fig. 3g). Significant peaks in $\mathrm{CH}_{2} \mathrm{I}_{2}$ and $\mathrm{CH}_{3} \mathrm{I}$ and the largest $\mathrm{N}$ deficit also occurred in this water.

\section{Discussion}

\subsection{Correlation analysis and VOI production}

Correlation analysis was performed to identify a potential correlation between VOIs, $\mathrm{Chl} a, \mathrm{NH}_{4}^{+}$, and $\mathrm{N}^{-}$deficit for 
Table 6. Concentrations of $\mathrm{CH}_{2} \mathrm{I}_{2}$ in each water type.

\begin{tabular}{|c|c|c|c|c|c|c|}
\hline St. & $\begin{array}{r}\mathrm{ML} \\
\mathrm{ACW}\end{array}$ & $\begin{array}{r}\text { ML } \\
\text { PMLW }\end{array}$ & $\begin{array}{r}\mathrm{bML} \\
\mathrm{ACW}\end{array}$ & $\begin{array}{r}\text { bML BSAW } \\
\text { BSAW }\end{array}$ & CDW & AW \\
\hline 1 & \multicolumn{6}{|c|}{ Southern Chukchi shelf } \\
\hline 10 & 0.65 & & 2.45 & 4.00 & & \\
\hline 14 & 7.20 & & 9.95 & & & \\
\hline 80 & 2.63 & & & 9.10 & & \\
\hline 78 & 3.80 & & 6.10 & 6.30 & & \\
\hline 76 & 0.80 & & 6.20 & & & \\
\hline 74 & 9.38 & & 13.90 & & & \\
\hline \multicolumn{7}{|c|}{ Central Chukchi shelf-slope } \\
\hline 53 & 2.77 & & 5.40 & 10.10 & 9.80 & 1.70 \\
\hline 60 & 4.20 & & 5.55 & 4.20 & 7.60 & 0.20 \\
\hline 48 & 4.10 & & 11.30 & & 0.60 & 0.27 \\
\hline 68 & & 3.60 & 6.90 & 5.15 & 13.40 & 0.20 \\
\hline 45 & 1.50 & & & 1.60 & 0.85 & 0.10 \\
\hline 72 & & 0.27 & & 1.00 & 5.90 & \\
\hline 24 & & 0.10 & & 2.37 & 20.90 & \\
\hline \multicolumn{7}{|c|}{ Northern slope-basin } \\
\hline 29 & & 0.00 & & 7.40 & 1.30 & 0.45 \\
\hline 33 & & 0.00 & & 0.60 & 2.30 & 0.03 \\
\hline 39 & & 0.05 & & 1.45 & 0.15 & 0.00 \\
\hline 32 & & 0.03 & & 1.55 & 0.35 & 0.03 \\
\hline 64 & & 0.00 & & 0.47 & & 0.04 \\
\hline
\end{tabular}

High $\mathrm{CH}_{2} \mathrm{I}_{2}\left(>4.4 \mathrm{pmol} \mathrm{L}^{-1}\right)$ values above the total average in Pacific-origin water are denoted in bold.

all the samples and ACW and BSAW-PMLW-CDW samples. The correlation coefficients are summarized in Table 8 . Scattering diagrams of VOIs as compared to $\mathrm{NH}_{4}^{+}$are shown in Fig. 4.

High correlations were found in the BSAW/PMLW/CDW between $\mathrm{NH}_{4}^{+}$and three VOIs: $\mathrm{CH}_{3} \mathrm{I}(R=0.77, P<0.01$, $n=64), \mathrm{C}_{2} \mathrm{H}_{5} \mathrm{I}(R=0.93, P<0.01, n=64)$, and $\mathrm{CH}_{2} \mathrm{ClI}$ $(R=0.66, P<0.01, n=64)$. High correlations were also found between $\mathrm{N}$ deficit and $\mathrm{CH}_{2} \mathrm{I}_{2}(R=0.67, P<0.01$, $n=64)$. Other nutrient components $\left(\mathrm{NO}_{3}^{-}, \mathrm{NO}_{2}^{-}, \mathrm{PO}_{4}^{3-}\right.$, $\mathrm{SiO}_{2}$ ) showed lower correlations with VOIs than $\mathrm{NH}_{4}^{+}$and $\mathrm{N}$ deficit.

We could not find any correlation between VOIs and Chl $a$, even though previous incubation experiments have indicated that many marine phytoplankton species produce VOIs as they grow (Tokarczyk and Moore, 1994; Moore et al., 1996; Manley and de la Cuesta, 1997). However, high and low concentrations of VOIs in surface seawater have also been attributed to varying high and low biological productivity in different types of water (e.g., from tropical to polar) and different sea areas (shelf, slope, basin; Ooki et al., 2015). It seems that Chl $a$ is not a main factor in the verticalhorizontal distributions of VOIs on a regional scale, such as the Chukchi Sea and adjacent sea area, implying that large fractions of VOI abundances in coastal sea area were not directly emitted from living phytoplankton, as discussed in later Sects. 4.1.1 and 4.1.2.
Table 7. Concentrations of $\mathrm{CH}_{2} \mathrm{ClI}$ in each water type.

\begin{tabular}{|c|c|c|c|c|c|c|}
\hline St. & $\begin{array}{r}\mathrm{ML} \\
\mathrm{ACW}\end{array}$ & $\begin{array}{r}\text { ML } \\
\text { PMLW }\end{array}$ & $\begin{array}{l}\mathrm{bML} \\
\mathrm{ACW}\end{array}$ & $\begin{array}{r}\text { bML } \\
\text { BSAW }\end{array}$ & $\mathrm{CDW}$ & AW \\
\hline & \multicolumn{6}{|c|}{ Southern Chukchi shelf } \\
\hline 1 & 10.95 & & 7.70 & & & \\
\hline 10 & 5.90 & & 7.10 & 3.95 & & \\
\hline 14 & 17.80 & & 13.35 & & & \\
\hline 80 & 5.97 & & & 4.80 & & \\
\hline 78 & 8.37 & & 9.40 & 5.65 & & \\
\hline 76 & 3.50 & & 4.83 & & & \\
\hline \multirow[t]{2}{*}{74} & 12.68 & & 14.60 & & & \\
\hline & \multicolumn{6}{|c|}{ Central Chukchi shelf-slope } \\
\hline 53 & 6.93 & & 6.05 & 5.10 & 4.30 & 0.70 \\
\hline 60 & 9.60 & & 6.55 & 3.10 & 2.90 & 0.20 \\
\hline 48 & 10.60 & & 7.50 & & 0.50 & 0.13 \\
\hline 68 & 10.45 & & 8.00 & 3.10 & 4.60 & 0.08 \\
\hline 45 & 4.23 & & & 1.37 & 0.60 & 0.00 \\
\hline 72 & & 2.00 & & 3.50 & 5.30 & \\
\hline 24 & & 0.50 & & 3.70 & 11.00 & \\
\hline \multicolumn{7}{|c|}{ Northern slope-basin } \\
\hline 29 & & 0.20 & & 2.10 & 1.90 & 0.25 \\
\hline 33 & & 0.25 & & 1.30 & 2.15 & 0.13 \\
\hline 39 & & 0.58 & & 1.10 & 0.55 & 0.00 \\
\hline 32 & & 0.17 & & 1.35 & 0.70 & 0.03 \\
\hline 64 & & 0.23 & & 1.00 & & 0.02 \\
\hline
\end{tabular}

High $\mathrm{CH}_{2} \mathrm{ClI}\left(>5.0 \mathrm{pmol} \mathrm{L}^{-1}\right)$ above the total average in Pacific-origin water are denoted in bold.

\subsubsection{Production of iodomethane $\left(\mathrm{CH}_{3} \mathrm{I}\right)$ and iodoethane $\left(\mathrm{C}_{2} \mathrm{H}_{5} \mathrm{I}\right)$}

The significant correlation between $\mathrm{C}_{2} \mathrm{H}_{5} \mathrm{I}$ and $\mathrm{NH}_{4}^{+}$implies that $\mathrm{C}_{2} \mathrm{H}_{5} \mathrm{I}$ production in seawater occurs at the same time as regeneration of $\mathrm{NH}_{4}^{+}$from organic matter. The $\mathrm{C}_{2} \mathrm{H}_{5} \mathrm{I}$ consumption, which is probably bacterial consumption, might occur at a rate similar to the biological $\mathrm{NH}_{4}^{+}$consumption. The consumption rates for $\mathrm{NH}_{4}^{+}$in seawater over the Chukchi Sea shelf are reported to vary widely from $0.15-3.6 \mathrm{nmol} \mathrm{L}^{-1}$ $\mathrm{d}^{-1}$ (Christman et al., 2011) to $0.24-7.2 \mu \mathrm{mol} \mathrm{L}^{-1} \mathrm{~d}^{-1}$ (Souza et al., 2014), with a variable turnover from within 1 day to over 10 days. The high correlation between $\mathrm{CH}_{3} \mathrm{I}$ and $\mathrm{NH}_{4}^{+}(R=0.77)$ would also be attributable to the $\mathrm{CH}_{3} \mathrm{I}$ production linked to the degradation of organic matter.

Note that two data points below the linear regression line in Fig. 4 are the data collected from the bottom layer water at the Hope Valley biological hotspot (St10) with high nutrients and low dissolved oxygen. We do not currently propose a reason for this exceptional plot.

The production of $\mathrm{C}_{2} \mathrm{H}_{5} \mathrm{I}$ and $\mathrm{CH}_{3} \mathrm{I}$ associated with the bacterial degradation of organic matter was first demonstrated by an incubation experiment for marine biogenic aggregates, which mainly consisted of diatoms collected from the Arctic seawater. The concentrations of $\mathrm{C}_{2} \mathrm{H}_{5} \mathrm{I}$ and $\mathrm{CH}_{3} \mathrm{I}$ 
Table 8. Correlation coefficients $R$ (all water types $(n=147) /$ warm ACW $(n=54) /$ cold BSAW-PMLW-CDW $(n=64))$.

\begin{tabular}{|c|c|c|c|c|c|c|c|}
\hline & $\mathrm{CH}_{3} \mathrm{I}$ & $\mathrm{C}_{2} \mathrm{H}_{5} \mathrm{I}$ & $\mathrm{CH}_{2} \mathrm{I}_{2}$ & $\mathrm{CH}_{2} \mathrm{CII}$ & $\mathrm{NH}_{4}^{+}$ & Chl $a$ & $\mathrm{~N}$ deficit \\
\hline $\mathrm{CH}_{3} \mathrm{I}$ & & $0.73 / 0.71 / 0.76$ & $0.55 / 0.47 / \mathbf{0 . 8 4}$ & $0.55 / 0.21 * / 0.91$ & $\mathbf{0 . 7 0} / 0.43 / \mathbf{0 . 7 7}$ & $0.41 / 0.28 * / 0.09^{*}$ & $\mathbf{0 . 6 1} / 0.49 / \mathbf{0 . 6 3}$ \\
\hline $\mathrm{C}_{2} \mathrm{H}_{5} \mathrm{I}$ & $0.73 / 0.71 / 0.76$ & & $0.27 / 0.08^{*} / \mathbf{0 . 7 3}$ & $0.24 / 0.10 * / \mathbf{0 . 7 0}$ & $0.90 / 0.79 / 0.93$ & $0.05^{*} / 0.07^{*} / 0.11^{*}$ & $0.59 / \mathbf{0 . 7 6} / \mathbf{0 . 6 1}$ \\
\hline $\mathrm{CH}_{2} \mathrm{I}_{2}$ & $0.55 / 0.47 / \mathbf{0 . 8 4}$ & $0.27 / 0.08 * / \mathbf{0 . 7 3}$ & & $0.50 / 0.27^{*} / \mathbf{0 . 8 5}$ & $0.23 / 0.05 * / \mathbf{0 . 6 4}$ & $\mathbf{0 . 6 2 / 0 . 6 4 / 0 . 1 3 ^ { * }}$ & $0.22 / 0.01^{*} / \mathbf{0 . 6 7}$ \\
\hline $\mathrm{CH}_{2} \mathrm{ClI}$ & $0.55 / 0.21 * / 0.91$ & $0.24 / 0.10^{*} / \mathbf{0 . 7 0}$ & $0.50 / 0.27^{*} / \mathbf{0 . 8 5}$ & & $0.31 / 0.10 * / \mathbf{0 . 6 6}$ & $\mathbf{0 . 6 9} / 0.30^{*} / 0.18^{*}$ & $0.29 / 0.03 * / \mathbf{0 . 6 3}$ \\
\hline $\mathrm{NH}_{4}^{+}$ & $\mathbf{0 . 7 0} / 0.43 / \mathbf{0 . 7 7}$ & $0.90 / 0.79 / 0.93$ & $0.23 / 0.05 * / 0.64$ & $0.31 / 0.10 * / 0.66$ & & $0.06 / 0.32 * / 0.08 *$ & $0.52 / \mathbf{0 . 6 8} / 0.55$ \\
\hline $\mathrm{Chl}^{4} a$ & $0.41 / 0.28^{*} / 0.09^{*}$ & $0.05^{*} / 0.07 * / 0.11^{*}$ & $0.62 / 0.64 / 0.13^{*}$ & $0.69 / 0.30^{*} / 0.18^{*}$ & $0.06 / 0.32 * / 0.08 *$ & & $0.20 * / 0.18^{*} / 0.04^{*}$ \\
\hline $\mathrm{N}$ deficit & $0.61 / 0.49 / 0.63$ & $0.59 / \mathbf{0 . 7 6} / 0.61$ & $0.22 / 0.01 * / 0.67$ & $0.29 / 0.03^{*} / 0.63$ & $0.52 / 0.68 / 0.55$ & $0.20 * / 0.18 * / 0.04^{*}$ & \\
\hline
\end{tabular}

All water types: $\mathrm{ACW}+\mathrm{BSAW}+\mathrm{PMLW}+\mathrm{CDW}+\mathrm{AW} ; p$ value $<0.01 ;{ }^{*} p$ value $>0.01$.

(a)

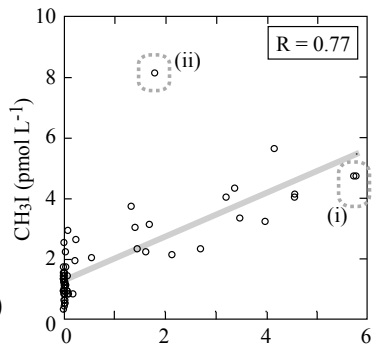

(c)

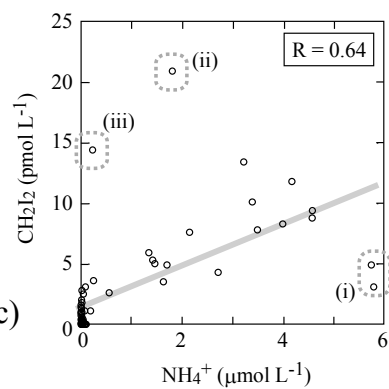

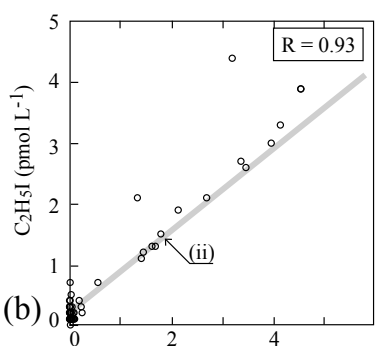

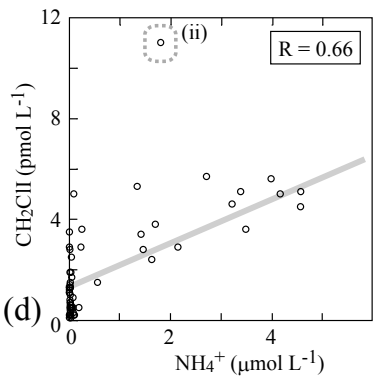

Figure 4. Scatterplots of $\mathrm{CH}_{3} \mathrm{I}$ and $\mathrm{NH}_{4}^{+}$(a), $\mathrm{C}_{2} \mathrm{H}_{5} \mathrm{I}$ and $\mathrm{NH}_{4}^{+}$(b), $\mathrm{CH}_{2} \mathrm{I}_{2}$ and $\mathrm{NH}_{4}^{+}$(c), and $\mathrm{CH}_{2} \mathrm{ClI}$ and $\mathrm{NH}_{4}^{+}$(d). Dashed lines enclose the following: data for St10 in the subsurface bottom layer water of the Hope Valley biological hotspot (i); data for St24 in the bottom layer water over the northern tip of the Chukchi Sea shelf (ii); and data for St29 in the subsurface BSAW (48 m) over the northern slope area (iii).

in the incubation vessel increased sharply, simultaneously with the enhancement of the bacterial heterotrophic production rate (Hughes et al., 2008).

Previously, $\mathrm{NH}_{4}^{+}$concentrations in coastal subarctic seawater have been observed to increase in the bottom layer water ( $\sim 90 \mathrm{~m}$ depth) after the spring bloom of diatoms (Kudo et al., 2007). Therefore, we suggest that the production of $\mathrm{C}_{2} \mathrm{H}_{5} \mathrm{I}$ and $\mathrm{CH}_{3} \mathrm{I}$ associated with the degradation of organic matter occurs in the bottom layer water, probably after the diatom bloom, over the Chukchi Sea shelf.

\subsubsection{Production of diiodomethane $\left(\mathrm{CH}_{2} \mathrm{I}_{2}\right)$ and chloroiodomethane $\left(\mathrm{CH}_{2} \mathrm{ClI}\right)$}

The notable feature of $\mathrm{CH}_{2} \mathrm{I}_{2}$ and $\mathrm{CH}_{2} \mathrm{ClI}$ distributions was that high concentration peaks were found 1) in the CDW and

subsurface BSAW over the Chukchi Sea shelf (St24, St53, St60, St72) and slope (St68), where large N deficit and high $\mathrm{NH}_{4}^{+}$concentration occurred simultaneously, and 2) at the northern Chukchi Sea slope (St29), where large $\mathrm{N}$ deficit and low $\mathrm{NH}_{4}^{+}$concentration occurred simultaneously. Concentration peaks in $\mathrm{C}_{2} \mathrm{H}_{5} \mathrm{I}$ and $\mathrm{CH}_{3} \mathrm{I}$ were not found over the northern slope area $(\mathrm{St} 29)$ where $\mathrm{NH}_{4}^{+}$concentration was low.

From the marine biogenic aggregates incubation (Hughes et al., 2008) mentioned in the last section, the concentrations of $\mathrm{CH}_{2} \mathrm{I}_{2}$ and $\mathrm{CH}_{2} \mathrm{ClI}$ did not increase in the incubation vessel during the incubation period of $70 \mathrm{~h}$, whereas $\mathrm{C}_{2} \mathrm{H}_{5} \mathrm{I}$ showed significant increases in concentration with the enhancement of the bacterial production rate after $30 \mathrm{~h}$ of incubation. It is possible that the production processes of $\mathrm{CH}_{2} \mathrm{I}_{2}$ in bottom layer water are quite different from those of $\mathrm{C}_{2} \mathrm{H}_{5} \mathrm{I}$, even if the production of both VOIs is associated with the degradation of organic matter in the sediment or the bottom layer water.

Recent studies have suggested that the production of $\mathrm{CH}_{2} \mathrm{I}_{2}$ in seawater occurs after the reaction of organic matter with $\mathrm{I}_{2}$, which is known as the "iodoform $\left(\mathrm{CHI}_{3}\right)$ reaction." The production of $\mathrm{CHI}_{3}$ and $\mathrm{CH}_{2} \mathrm{I}_{2}$ has been shown to occur after the reaction of dissolved organic matter with $\mathrm{I}_{2}$, which is produced by $\mathrm{I}^{-}$oxidizing bacteria in a culture vessel (Fuse et al., 2003; Amachi et al., 2005). It is noted that small amounts of $\mathrm{CH}_{2} \mathrm{ClI}$ and $\mathrm{CH}_{3} \mathrm{I}$ have been detected in the culture vessel with drastic increases in $\mathrm{CH}_{2} \mathrm{I}_{2}$, whereas $\mathrm{C}_{2} \mathrm{H}_{5} \mathrm{I}$ production has not yet been detected in the iodoform reaction.

The production of $I_{2}$ in seawater is believed to be initiated by $\mathrm{I}^{-}$oxidations. However, it remains unclear where the $\mathrm{I}^{-}$ oxidations occur in the ocean environment. Recently, iodideoxidizing bacteria, which oxidize iodide $\left(\mathrm{I}^{-}\right)$to molecular iodine $\left(I_{2}\right)$, have been detected in natural seawater samples after incubation under iodide-rich conditions $\left(\sim 1 \mathrm{mmol} \mathrm{L}^{-1}\right.$; Amachi et al., 2005). Iodide-rich conditions have been found in pore water of ocean sediment, with an $\mathrm{I}^{-}$concentration of $\sim 7 \mu \mathrm{mol} \mathrm{L}{ }^{-1}$, which is 70 to 700 times the seawater concentration (10-100 nmol L ${ }^{-1}$; Anschutz et al., 2000). Iodideoxidizing bacteria might actively produce $\mathrm{I}_{2}$ in pore water of the ocean sediment. Therefore, it is supposed that $\mathrm{I}_{2}$ production by $\mathrm{I}^{-}$-oxidizing bacteria in the sediment over the 
Chukchi Sea shelf has resulted in the production of $\mathrm{CH}_{2} \mathrm{I}_{2}$, $\mathrm{CH}_{2} \mathrm{ClI}$, and $\mathrm{CH}_{3} \mathrm{I}$ in the sediment or the bottom layer water.

Moreover, iodide can be oxidized by nitrate in a reaction that yields $\mathrm{N}_{2}$ and $\mathrm{I}_{2}$ in marine sediments (Anschutz et al., 2000):

$\mathrm{I}^{-}+1 / 5 \mathrm{NO}_{3}^{-}+6 / 5 \mathrm{H}^{+}=1 / 10 \mathrm{~N}_{2}+1 / 2 \mathrm{I}_{2}+3 / 5 \mathrm{H}_{2} \mathrm{O}$.

This reaction, which is thermodynamically favorable at all $\mathrm{pH}$ levels encountered in marine sediments $(\mathrm{pH}<8)$, would promote denitrification. Therefore, we suppose that the high concentrations of $\mathrm{CH}_{2} \mathrm{I}_{2}$ and $\mathrm{CH}_{2} \mathrm{ClI}$ in the bottom layer water and CDW over the Chukchi Sea shelf-slope areas, with the large $\mathrm{N}$ deficit, were linked to denitrification in the sediment.

\subsection{Lateral transport of VOIs}

The significant concentration peaks in the four VOIs in the CDW over the northern shelf-slope suggest the lateral transport of VOIs through the CDW layer from the shelf to the basin area, as well as the transport of humic-like DOM, nutrients, and dissolved Fe (Hioki et al., 2014) - which are all believed to be derived from organic-matter decomposition in the sediment over the shelf.

High concentrations of $\mathrm{CH}_{2} \mathrm{ClI}$ in the surface mixed layer over the Central Chukchi shelf-slope would be due to the lateral transport of $\mathrm{ACW}$ from the Bering Strait and the southern Chukchi Sea. Lateral transport of $\mathrm{CH}_{3} \mathrm{I}, \mathrm{C}_{2} \mathrm{H}_{5} \mathrm{I}$, and $\mathrm{CH}_{2} \mathrm{I}_{2}$ in $\mathrm{ACW}$ through the surface mixed layer to the Central Chukchi shelf-slope was not observed.

The lateral transport of $\mathrm{CH}_{2} \mathrm{ClI}$ from the Chukchi Sea to the northern Canada Basin in ACW through the mixed layer, and to the Alpha Ridge $\left(85^{\circ} \mathrm{N}\right)$ in the Pacific-origin CDW through the subsurface upper halocline layer has recently been reported by Karlsson et al. (2013). The VOIs produced over the Chukchi Sea shelf might have the potential to supply iodine to Arctic air far from the shelf.

\section{Summary}

Shipboard observation was conducted over the Chukchi Sea shelf-slope and the Canada Basin in the western Arctic Ocean in September and October 2012 by the R/V Mirai (MR12-E03) as part of the GRENE Arctic Climate Change Research Project. The purpose of the study was to obtain vertical distributions of iodomethane $\left(\mathrm{CH}_{3} \mathrm{I}\right)$, iodoethane $\left(\mathrm{C}_{2} \mathrm{H}_{5} \mathrm{I}\right)$, diiodomethane $\left(\mathrm{CH}_{2} \mathrm{I}_{2}\right)$, and chloroiodomethane $\left(\mathrm{CH}_{2} \mathrm{ClI}\right)$ in seawater. The following is a summary of the characteristics of the vertical distributions of these VOIs and hypotheses concerning lateral transport of VOIs in the area and mechanisms responsible for their production in relation to the degradation of organic matter.

High concentrations of four VOIs were found in the bottom layer water over the Chukchi Sea shelf, in which layer the concentration maximum of ammonium $\left(\mathrm{NH}_{4}^{+}\right)$occurred simultaneously. High correlations were found between $\mathrm{NH}_{4}^{+}$ and $\mathrm{C}_{2} \mathrm{H}_{5} \mathrm{I}$ with correlation coefficient $R=0.93$ and between $\mathrm{NH}_{4}^{+}$and $\mathrm{CH}_{3} \mathrm{I}$ with $R=0.77$. These results suggest that production of these VOIs is related to degradation of organic matter. The significant correlation between $\mathrm{C}_{2} \mathrm{H}_{5} \mathrm{I}$ and $\mathrm{NH}_{4}^{+}$implies similar consumption rates for both compounds in seawater, probably owing to bacterial consumption. Over the central and northern Chukchi Sea shelf-slope areas, concentration maxima of $\mathrm{CH}_{2} \mathrm{I}_{2}, \mathrm{CH}_{2} \mathrm{ClI}$, and $\mathrm{CH}_{3} \mathrm{I}$ were found in the subsurface BSAW and CDW alongside large $\mathrm{N}$ deficits and low concentrations of $\mathrm{NH}_{4}^{+}$. These results suggest that the production of the three VOIs is quite different from the production process of $\mathrm{C}_{2} \mathrm{H}_{5} \mathrm{I}$, while the productions of the four VOIs are all suspected to be relevant to the decompositions of organic matter in the sediment or the bottom layer water over the shelf.

Concentration peaks in four VOIs in the subsurface BSAW and CDW over the northern Chukchi Sea slope, and the peaks in $\mathrm{CH}_{2} \mathrm{CII}$ in the surface ACW over the Central Chukchi shelf-slope, suggest lateral transport from the Chukchi Sea shelf to slope-basin areas. The production of VOIs over the Chukchi Sea, in relation to decomposition of organic matter created in the highly productive Chukchi Sea shelf, would have the potential to supply iodine to Arctic air far from the shelf.

Author contributions. A. Ooki and S. Kawasaki measured VOIs in seawater and analyzed the data. K. Kuma, S. Nishino, and T. Kikuchi designed the ship observation. A. Ooki, S. Kawasaki, S. Nishino, and T. Kikuchi carried out the observation. A. Ooki prepared the manuscript with contributions from all co-authors.

Acknowledgements. We thank the captain, officers, and crew of the $R / V$ Mirai, which was operated by Global Ocean Development, Inc. We also thank the staff of Marine Works Japan, Ltd., for their skillful work aboard the ship and for data processing and A. Fujiwara for preparing the SST map from satellite data. This study was supported by GRENE Arctic Climate Change Research Project and by JSPS KAKENHI Grant Number 24681001.

Edited by: M. Yamamoto-Kawai

\section{References}

Amachi, S., Muramatsu, Y., Akiyama, Y., Miyazaki, K., Yoshiki, S., Hanada, S., Kamagata, Y., Ban-nai, T., Shinoyama, H., and Fujii, T.: Isolation of iodide-oxidizing bacteria from iodide-rich natural gas brines and seawaters, Microb. Ecol., 49, 547-557, doi:10.1007/s00248-004-0056-0, 2005.

Anderson, L. G., Andersson, P. S., Bjork, G., Jones, E. P., Jutterstrom, S., and Wahlstrom, I.: Source and formation of the upper halocline of the Arctic Ocean, J. Geophys. Res., 118, 410-421, doi:10.1029/2012JC008291, 2013. 
Anschutz, P., Sundby, B., Lefrancois, L., Luther, G.W., and Mucci, A.: Interactions between metal oxides and species of nitrogen and iodine in bioturbated marine sediments, Geochim. Cosmochim. Acta, 64, 2751-2763, doi:10.1016/S00167037(00)00400-2, 2000.

Archer, S. D., Goldson, L. E., Liddicoat, M. I., Cummings, D. G., and Nightingale, P. D.: Marked seasonality in the concentrations and sea-to-air flux of volatile iodocarbon compounds in the western English Channel, J. Geophys. Res., 112, C08009, doi:10.1029/2006JC003963, 2007.

Atkinson, H. M., Hughes, C., Shaw, M. J., Roscoe, H. K., Carpenter, L. J., and Liss, P. S.: Halocarbons associated with Arctic sea ice, Deep-Sea Res., 92, 162-175, doi:10.1016/j.dsr.2014.05.012, 2014.

Carpenter, L. J., Sturges, W. T., Penkett, S. A., Liss, P. S., Alicke, B., Hebestreit, K., and Platt U.: Short-lived alkyl iodides and bromides at Mace Head, Ireland: Links to biogenic sources and halogen oxide production, J. Geophys. Res., 104, 1679-1689, doi:10.1029/98JD02746, 1999.

Carpenter, L. J., Hopkins, J. R., Jones, C. E., Lewis, A. C., Parthipan, R., Wevill, D. J., Poissant, L., Pilote, M., and Constant, P.: Abiotic source of reactive organic halogens in the sub-arctic atmosphere, Environ. Sci. Technol. 39, 8812-8816, doi:10.1021/es050918w, 2005.

Christman, G. D., Cottrell, M. T., Popp, B. N., Gier, E., and Kirchman, D. L.: Abundance, Diversity, and Activity of AmmoniaOxidizing Prokaryotes in the Coastal Arctic Ocean in Summer and Winter, Appl. Environ. Microbiol., 77, 2026-2034, doi:10.1128/AEM.01907-10, 2011.

Codispoti, L. A., Flagg, C., Kelly, V., and Swift, J. H.: Hydrographic conditions during the 2002 SBI process experiments, DeepSea Res. Pt. II, 52, 3199-3226, doi:10.1016/j.dsr2.2005.10.007, 2005.

Cota, G. F., Pomeroy, L. R., Harrison, W. G., Jones, E. P., Peters, F., Sheldon, W. M., and Weingartner, T. R.: Nutrients, primary production and microbial heterotrophy in the southeastern Chukchi Sea: Arctic summer nutrient depletion and heterotrophy, Mar. Ecol.-Prog. Ser., 135, 247-258, doi:10.3354/meps135247, 1996.

Fuse, H., Inoue, H., Murakami, K., Takimura, O., and Yamaoka, Y.:Production of free and organic iodine by Roseovarius spp., FEMS Microbiol. Lett., 229, 189-194, doi:10.1016/S03781097(03)00839-5, 2003.

Grebmeier, J. M., McRoy, C. P., and Feder, H. M.: Pelagic-benthic coupling on the shelf of the northern Bering and Chukchi Seas I., Food supply source and benthic biomass, Mar. Ecol.-Prog. Ser., 48, 57-67, 1988.

Grebmeier, J. M., Feder, H. M., and McRoy, C. P.: Pelagic-benthic coupling on the shelf of the northern Bering and Chukchi Seas II., Benthic community structure, Mar. Ecol.-Prog. Ser., 51, 253268, 1989.

Grebmeier, J. M., Bluhm, B. A., Cooper, L. W., Danielson, S., Arrigo, K. R., Blanchard, A. L., Clarke, J. T., Day, R. H., Frey, K. E., Gradinger, R. R., Kedra, M., Konar, B., Kuletz, K. J., Lee, S. H., Lovvorn, J. R., Norcross, B. L., and Okkonen, S. R.:Ecosystem Characteristics and Processes Facilitating Persistent Macrobenthic Biomass Hotspots and Associated Benthivory in the Pacific, Arctic. Prog. Oceanogr., 136, 92-114, doi:10.1016/j.pocean.2015.05.006, 2015.
Happell, J. D. and Wallace, D. W. R.: Methyl iodide in the Greenland/Norwegian Seas and the tropical Atlantic Ocean: Evidence for photochemical production, Geophys. Res. Lett., 23, 21052108, doi:10.1029/2006JC003963, 1996.

Hioki, N., Kuma, K., Morita, Y., Sasayama, R., Ooki, A., Kondo, Y., Obata, H., Nishioka, J., Yamashita, Y., Nishino, S., Kikuchi, T., and Aoyama, M.: Laterally spreading iron, humic-like dissolved organic matter and nutrients in cold, dense subsurface water of the Arctic Ocean, Scientific Reports, 4, 6775, doi:10.1038/srep06775, 2014.

Hughes, C., Malin, G., Turley, C. M., Keely, B. J., and Nightingale, P. D.: The production of volatile iodocarbons by biogenic marine aggregates, Liminol. Oceanogr., 53, 867-872, doi:10.4319/lo.2008.53.2.0867, 2008.

Hydes, D. J., Aoyama, M., Aminot, A., Bakker, K., Becker, S., Coverly, S., Daniel, A., Dickson, A. G., Grosso, O., Kerouel, R., van Ooijen, J., Sato, K., Tanhua, T., Woodward, E. M. S., and Zhang, J. Z.: Determination of dissolved nutrients $(\mathrm{N}, \mathrm{P}, \mathrm{Si})$ in seawater with high precision and inter-comparability using gas-segmented continuous flow analysers. The GO-SHIP Repeat Hydrography Manual: A Collection of Expert Reports and Guidelines, ICPO publ, Ser. no. 134, edited by: Hood, E. M., Sabine, C. L., and Sloyan, B. M., IOCCP Rep. 14, U. N. Educ.Sci. and Cult. Organ. Intergov. Oceanotr. Comm., Paris, 1-88, 2010.

Jones, C. E. and Carpenter, L. J.: Solar photolysis of CH2I2, $\mathrm{CH} 2 \mathrm{ICI}$, and $\mathrm{CH} 2 \mathrm{IBr}$ in water, saltwater, and seawater, Environ. Sci. Technol., 39, 6130-6137, doi:10.1021/es050563g, 2005.

Karlsson, A., Theorin, M., and Abrahamsson, K.: Distribution, transport, and production of volatile halocarbons in the upper waters of the ice-covered high Arctic Ocean, Global Biogeochem. Cy., 27, 1246-1261, doi:10.1002/2012GB004519, 2013.

Kudo, I., Yoshimura, T., Lee, C.W., Yanada, M., and Maita, Y.: Nutrient regeneration at bottom after a massive spring bloom in a subarctic coastal environment, Funka Bay, Japan, J. Oceanogr. 63, 791-801, doi:10.1007/s10872-007-0067-9, 2007.

Manley, S. L. and de la Cuesta, J. L.: Methyl iodide production from marine phytoplankton cultures, Limnol. Oceanogr., 42, 142-147, doi:10.1029/2006JC003963, 1997.

Mattson, E., Karlsson, A., Smith, W. O., and Abrahamsson, K.: The relationship between biophysical variables and halocarbon distributions in the waters of the Amundsen and Ross Seas, Antarctica, Mar. Chem. 140, 1-9, doi:10.1016/j.marchem.2012.07.002, 2012.

Moore, R. M., Webb, M., Tokarczyk, R., and Wever, R.: Bromoperoxidase and iodoperoxidase enzymes and production of halogenated methanes in marine diatom cultures, J. Geophys. Res. 101, 20899-20908, doi:10.1029/96JC01248, 1996.

Nishino, S., Shimada, K., and Itoh, M.: Use of ammonium and other nitrogen tracers to investigate the spreading of shelf waters in the western Arctic halocline, J. Geophys. Res., 110, C10005, doi:10.1029/2003JC002118, 2005.

Ooki, A. and Yokouchi Y.: Dichloromethane in the Indian Ocean: Evidence for in-situ production in seawater, Mar. Chem., 124, 119-124, doi:10.1016/j.marchem.2011.01.001, 2011a.

Ooki, A. and Yokouchi, Y.: Determination of Henry's law constant of halocarbons in seawater and analysis of sea-to-air flux of iodoethane $(\mathrm{C} 2 \mathrm{H} 5 \mathrm{I})$ in the Indian and Southern oceans based on partial pressure measurements, Geochem. J., 45, E1-E7, 2011 b. 
Ooki, A., Nomura, D., Nishino, S., Kikuchi, T., and Yokouchi, Y.. A global-scale map of isoprene and volatile organic iodine in surface seawater of the Arctic, northwest Pacific, Indian, and Southern Oceans, 120, 4108-4128, J. Geophys. Res., doi:10.1002/2014JC010519, 2015.

Schall, C. and Heumann, K. G.: GC determination of volatile organoiodine and organobromine compounds in Arctic seawater and air samples, Fresenius, J. Anal. Chem., 346, 717-722, doi:10.1016/S0967-0645(02)00204-7, 1993.

Souza, A. C., Gardner, W. S., and Dunton, K. H.: Rates of nitrification and ammonium dynamics in northeastern Chukchi Sea shelf waters, Deep Sea Res., 102, 68-76, doi:10.1016/j.dsr2.2013.12.017, 2014.

Spicer, C. W., Plastridge, R. A., Foster, K. L., Finlayson-Pitts, B. J., Bottenheim, J. W. Grannas, A. M., and Shepson, P. B.: Molecular halogens before and during ozone depletion events in the Arctic at polar sunrise: concentrations and sources, Atmos. Environ., 36, 2721-2731, doi:10.1016/S1352-2310(02)00125-5, 2002.
Tokarczyk, R. and Moore, R.M.: Production of volatile organohalogens by phytoplankton cultures. Geophys. Res. Lett., 21, 285288, doi:10.1029/94GL00009, 1994.

Welshmeyer, N. A.: Fluorometric analysis of chlorophyll a in the presence of chlorophyll $\mathrm{b}$ and pheopigments, Limnol. Oceanogr., 39, 1985-1992, doi:10.4319/lo.1994.39.8.1985, 1994.

World Meteorological Organization (WMO): Scientific assessment of ozone depletion: 2010, Global Res. Monit. Proj. Rep. 52, Geneva, Switzerland, chapter 3, 2010. 